\title{
Civilian-Military Collaboration before and during COVID-19 Pandemic-A Systematic Review and a Pilot Survey among Practitioners
}

\author{
Amir Khorram-Manesh ${ }^{1,2, * \mathbb{D}}$, Luc J. Mortelmans ${ }^{3,4}{ }^{\mathbb{D}}$, Yohan Robinson ${ }^{1,2} \mathbb{D}$, Frederick M. Burkle ${ }^{5}$ and \\ Krzysztof Goniewicz ${ }^{6, *(1)}$ \\ 1 Institute of Clinical Sciences, Sahlgrenska Academy, Gothenburg University, 41345 Gothenburg, Sweden; \\ yohan.robinson@gu.se \\ 2 Department of Research and Development, Armed Forces Center for Defense Medicine, \\ 42676 Västra Frölunda, Sweden \\ 3 Center for Research and Education in Emergency Care, University of Leuven, 3000 Leuven, Belgium; \\ luc.mortelmans@zna.be \\ 4 Regedim, VUB, Brussels and Department of Emergency Medicine, ZNA, Stuivenberg, 2060 Antwerp, Belgium \\ 5 Harvard Humanitarian Initiative, T.H. Chan School of Public Health, Harvard University, Boston, MA 02115, \\ USA; skipmd77@aol.com \\ 6 Department of Security, Military University of Aviation, 08-521 Dẹblin, Poland \\ * Correspondence: amir.khorram-manesh@surgery.gu.se (A.K.-M.); k.goniewicz@law.mil.pl (K.G.)
}

\section{check for}

updates

Citation: Khorram-Manesh, A.; Mortelmans, L.J.; Robinson, Y.; Burkle, F.M.; Goniewicz, K. Civilian-Military Collaboration before and during COVID-19

Pandemic-A Systematic Review and a Pilot Survey among Practitioners. Sustainability 2022, 14, 624. https:// doi.org/10.3390/su14020624

Academic Editors: John Rennie Short and Marc A. Rosen

Received: 12 November 2021

Accepted: 5 January 2022

Published: 6 January 2022

Publisher's Note: MDPI stays neutral with regard to jurisdictional claims in published maps and institutional affiliations.

Copyright: (C) 2022 by the authors. Licensee MDPI, Basel, Switzerland. This article is an open access article distributed under the terms and conditions of the Creative Commons Attribution (CC BY) license (https:// creativecommons.org/licenses/by/ $4.0 /)$.

\begin{abstract}
Due to the similarity in skills and assets, Civilian-Military collaboration has emerged as one of the most reliable partnerships during the disaster and public health emergency management to address all necessary elements of surge capacity, i.e., staff, stuff, structure (space), and systems. This study aimed to evaluate this collaboration before and during the coronavirus 2019 pandemic. The outcomes of the systematic review revealed several published reports on successful civilian-military collaboration and proposed a need for further improvement. One hundred sixty-six individuals from 19 countries responded to nine questions, included in an online survey with the possibility to leave comments if necessary. The questionnaire referred to elements such as command and control, safety, communication, assessment, triage, treatment, and transport, as the crucial components of emergency management. The comprehensive examination of the survey results together with registered comments revealed a possible improvement in collaboration particularly on the strategic levels, i.e., meetings at the command-and-control level, safety, communication, and networking issues. While logistic collaboration seemed to be unchanged, the practical parts of the collaboration, i.e., clinical and non-clinical operational partnership (Triage and Treatment), mutual education, training, and operational understanding of each organization remained unchanged. In conclusion, although the current pandemic may have facilitated a more intense collaboration between civilian and military healthcare organizations, it lacks practical partnership and operative engagement, representing two crucial elements necessary for harmony and compatibility of both systems. Such collaboration may require a political will and perhaps a mutual civilian-military authority.
\end{abstract}

Keywords: civilian-military collaboration; interagency partnership; pandemic; public health

\section{Introduction}

Multiagency collaboration (MC) is universally accepted as an important part of the management of disasters and public health emergencies [1-5]. Among various factors influencing $\mathrm{MC}$, leadership and communication are seemingly the most crucial [3-5]. While experience and transparent leaderships govern the functional relationships and the clarity of the roles between various partners, insufficient leaderships create significant challenges to MC and influence the trust, understanding, and mutual respect between the agencies [6-9]. Moreover, good inter-and intra-organizational communication facilitates a 
successful collaboration, although requiring adequate resourcing and financial assets to achieve the established goals $[2,4,5]$.

Inter-organizational collaboration is a situation-dependent complex process with diversified scope, and structure, thus yielding different understandings, interpretations, and outcomes. Distinctions may arise when two organizations experience diverse responsibilities, autonomy, legacy, organizational framework, and authority structure $[10,11]$. Consequently, even well-formulated collaboration may fail to achieve its expected outcomes due to several factors, such as asymmetrical structures, and requires continuous supervision and cultivation [12-14].

\subsection{Theoretical Framework}

The collaboration aims at bringing two independent organizations together in a new structure, where they share the same commitments to conduct the same planning and mission to achieve the same outcomes, and ultimately produce or create something unique $[11,13,14]$. According to Vangen and Huxham [15], a successful collaboration consists of five perspectives:

1. Substantive outcomes (e.g., better use of funds and resources, increase in awareness)

2. High productivity

3. Emergent milestones (e.g., mutual and united targets, joint events, and considering each other's interests)

4. Recognizing and valuing their partnership

5. Creating individual and organizational pride to highlight their collaborative success and compatible organizational culture.

These perspectives are necessary for a successful relationship between two organizations and influence their aims, working processes, communication, trust, and accountability [16-18]. Considering these perspectives in civilian-military relations, Shanks Kaurin [19], proposes that the outcome will create five diverse situations when civilian-military populations:

1. Share values but have conflicting understanding.

2. Share values but have different priorities.

3. Share the process without sharing values.

4. Have no shared substantive or procedural values at all.

5. Are indifferent towards the outcomes of their actions.

Within healthcare, one way to measure the outcomes of collaboration is to use the acronym CSCATTT used in MIMMS (Major Incident Medical Management and Support) courses [20]. CSCATTT stands for C: Command and control; S: Safety; C: Communication; A: Assessment; T: Triage; T: Treatment; and T: Transport. These factors illustrate medical and non-medical aspects of disaster and emergency management and should be included in healthcare planning and response and synchronized with other organizations, such as the military healthcare, in collaboration to achieve a fruitful outcome.

Applying the described theoretical framework to the elements of CSCATTT may facilitate a unique opportunity to measure and evaluate changes in disaster and emergency management processes over time.

\subsection{Civilian-Military Collaboration in Healthcare}

Historically, Civilian-Military Collaboration (CMC) has connected both agencies in various areas, e.g., the pyrotechnics industry and clinical practice, but a formalized collaboration started in educational sectors when military staff established academic carriers in civilian universities [20-24]. Nowadays, an increasing number of public health emergencies, armed conflicts, and disasters, together with the global financial awareness and healthcarerelated technological developments, have enforced new constraints on the healthcare sector, necessitating a new round of CMC collaboration in healthcare [5,25-27]. Lessons learned indicate that $\mathrm{CMC}$ should become compatible in both medical and non-medical aspects to achieve desired results [3,4,28-32]. Medical factors that influence the outcomes of CMC 
include differences in triage systems, treatment and intervention alternatives, and logistics for patients' evacuation, while non-medical factors encompass differences in command and control and leadership, security, situation assessment, communication, information-sharing, and reporting systems $[3,4,33,34]$. These aspects are included in CSCATTT as essential elements of emergency management.

The coronavirus 2019 (COVID-19), as well as several others incidents, has resulted in several societal changes and revealed weaknesses and strengths of the current management system [27,35-37]. Political and economic-based decision-making has been one, affecting major public health decisions, preventing the crucial collaborative efforts in implementing public health strategies, and halting healthcare leaders from making unpopular but necessary public health decisions. The lack of proper communication has equally contributed to the failure in achieving the established goal, the inability of information sharing, and disrespect for medical decisions [36-43]. However, this pandemic has also provided a good opportunity to evaluate and compare the current collaboration with that reported in the past [11,40-47]. An evaluation is particularly crucial since disasters and public health emergencies are increasingly impacted by cross-border factors that place increasing demands on society to initiate a broader dialogue of partnership [27,45-48]. Moreover, it is important to not only review experts' publications but also the opinions of the operational populations to identify potential gaps in outcomes and comprehension.

This article attempts to identify the status of CMC before and after the COVID-19 pandemic, based on the aforementioned theoretical background and using CSCATTT, in two steps:

(1) A systematic review of published literature aims at evaluating the status of CMC, presenting researchers' viewpoints.

(2) A survey among civilian and military staff to investigate the individuals' perception of CMC at the operational level, using CSCATTT.

\section{Materials and Method}

\subsection{The Systematic Literature Review}

A systematic literature review was conducted, using the following search engines; Science Direct, Scopus, PubMed, Web of Science, and Gothenburg University's online library, according to the PRISMA (Preferred Reporting Items for Systematic Reviews and Meta-Analyses) guidelines to evaluate the status of CMC (Figure 1) [49]. The quality of each included study was assessed using Health Evidence Quality Assessment Tool (Appendix A) [50].

Inclusion criteria: Original research studies published in English (1995-2021).

Exclusion criteria: Conference papers, abstracts, reports, non-scientific publications.

Search string: Civilian Military Collaboration AND/OR Civilian Military Partnership, separately or in combination. The terms "collaboration" and "partnership" were chosen based on the definition provided by the Oxford dictionary, ensuring the words were synonymous [51].

Two authors assessed all abstracts and titles independently to agree on included and excluded articles. Whenever disagreed, the third author was consulted. After achieving a mutual consensus, the full texts of the studies were reviewed. The reasons for all excluded papers were documented. For included studies, data regarding the name of authors, article title, year of publication, the title of the journal, the used methods, main results, and conclusions were all collected in Appendix B. 


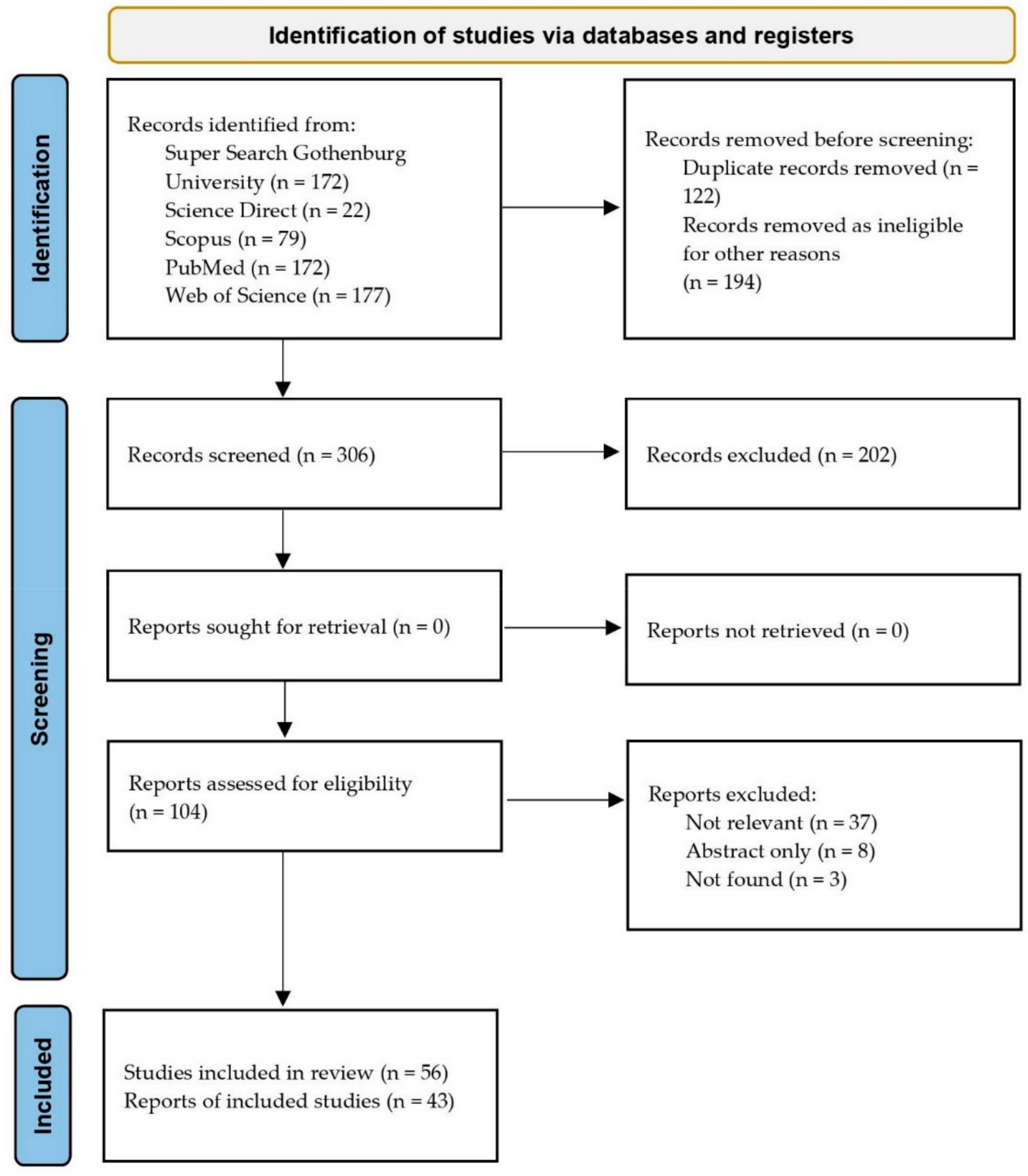

Figure 1. The process of literature selection according to PRISMA flow chart for new systematic reviews [49].

\subsection{Questionnaire Preparation}

The research group with experience from both civilian and military healthcare systems, formulated a questionnaire, consisting of eight questions, representing eight different dimensions, inspired by CSCATTT, i.e., Command and control, Safety, Communication, Assessment, Triage, Treatment, and Transport [20]. The tool identifies the leading strategic, tactical and operational parts of collaboration during emergencies $[2,3,11]$. Command and control encompassed three parts: administrative, practical, and mutual activities such as issuing directives and recommendations. The remaining five questions concerned safety and security issues, situational assessment, communication, medical issues, and logistics. The final questionnaire included free space to allow participants to include their comments (question 9). All authors reviewed, evaluated, and approved the questionnaire in consensus and based on a combination of clarity, logic, relevance, eligibility, comprehension, and usability. Each defined question could be answered by using a Likert scale, which was marked as 1 to 5 , where 1 was defined as a weak collaboration and 5 a strong collaboration, before and during the COVID-19 pandemic (Appendix C). 


\subsection{Distribution of the Questionnaire}

The research subject was introduced as a discussion topic on ResearchGate (RG), from 1 January to the end of May 2021. RG represents a European social networking site, engaging over 19 million scientists and researchers, being, the largest European academic network in terms of active users. The members of RG actively share papers, ask and answer questions voluntarily. They also find research collaborators [52]. Individuals interested in the topic could, after reading the purpose of the study, click on a link to a google document page and answer questions voluntarily (see "Ethical Considerations"). The use of the RG represents a so-called "virtual snowball sampling," method, which has been used in numerous studies [22,53-55]. The method helps to identify individuals of interest for this research, thus, allowing an increase in the representativeness of the results. It can also, increase the number of responses, is inexpensive, and decreases the sampling time. However, the sample selection is biased toward the characteristics of the online population like gender, age, education level, and socioeconomic belonging [53-55].

\subsection{Ethical Considerations}

The survey was anonymous, and all respondents agreed to participate voluntarily by clicking on the available link, where information about their participation and the purpose of the study was provided additionally. No name, affiliation, or other searchable information was registered. Confidentiality was strictly respected during data collection and obtained information was stored in a secure and safe area. The study complied with the ethical guidelines stipulated by Swedish law (SFS 2008:192). In Sweden, ethical approval is necessary if the research includes data regarding participants' race, ethnic heritage, political views, religion, sexual habits, or if it uses health or physical interventions or methods that aim to affect the person physically or psychologically (SFS 2003:460). Since this study did not include any of these aspects and all individuals freely contributed with their views on an available scientific site, it was exempt from ethics approval [22,55].

\subsection{Statistics}

Data were transferred to a spreadsheet, where the scores for each question before and under the COVID-19 pandemic were inserted. The mean and SD for each question before and during the pandemic was calculated, and the means were compared by using a $t$-test for the entire study cohort and each involved nation to obtain statistically significant changes, using a GraphPad Prism $t$-test calculator.

\section{Results}

\subsection{Literature Review}

The term, "Civilian-Military Collaboration", returned over 80,000 hits for all search engines. Using "Civilian-Military Collaboration" AND OR "Civilian-Military Partnership" in combination or separately resulted in a manageable number of references. Of the total 602 publications identified, 306 papers remained after removing duplicates and ineligible publications. These papers were sifted by looking at the abstracts, methods, and aims, and the eligible papers $(n=104)$, were studied in detail (Figure 1). Abstracts and non-relevant papers with no association to the main search key and case studies were removed. The final 43 papers were included and reported in Appendix B.

\subsection{The Core Findings of the Review}

There was a lack of consistency in defining civilian-military relations. While words such as coordination, cooperation, and collaboration were used interchangeably, the publication did not necessarily deal with collaboration. Furthermore, the majority of papers did not illustrate the view of practitioners, i.e., individuals who are operationally active in the field and were reviewed or presented the views of strategic level, researchers, or experts in the field. 
Although several authors reported the importance of CM cooperation in diverse fields like technological area [7], others reported that such cooperation results in a dual capacity building, which can enhance the integration between CM organizations, creating dual capacity and resource availability as a valuable advantage in prolonged disaster and emergency management [31]. However, besides a considerable cost, such integration causes primarily some confusion regarding the role of each organization in a specific event or activity, including pandemics $[6,23,30,45]$. It is well recognized that CM collaboration has resulted in advances in medical treatment of injuries, reduction of the number of deaths, and improvement of the Emergency Medical Systems. However, there seems to remain a need for new guidelines and directives to guarantee the benefits of such cooperation for both organizations and to eliminate or at least minimize some of the challenges between the two organizations, such as, in leadership, operative, and logistics partnership $[3,4,9,24,46]$. One way to make these organizations compatible seems to be mutual educational and training initiatives $[25,30,56]$, which not only synchronize their activities but equally help clear the role and responsibility of each organization, joint operating mechanism, and treatment policies and reduce the organizational tensions that may exist between two populations [57].

The lack of trust has been reported as one of the core arguments for an insufficient engagement between two organizations $[9,22,28]$. Sharing information, planning, and developing a mutual administrative working activity, may however help to increase the trust between two organizations and enhance the development of a valuable partnership in all aspects of integration. Within healthcare, there are several contact points between civilian and military organizations $[3,4,22,28]$. Following the CSCATTT acronym, there is a need for synchronization between these two populations in leadership, safety, and communication issues to achieve mutual assessment of the situation. Such synchronization enables both organizations to achieve and obtain the advantages of dual capacity in staff, stuff, space, and system, i.e., all crucial elements of surge capacity, and in the outcomes of treatment and survival [3,4,32,35,58,59].

Although educational initiatives and training courses-besides other types of planning programs - are associated with a cost [60], they enable a multiagency collaboration that encompasses all agencies and not only, CM. These initiatives clarify the roles, increase the skills, and pave the way for achieving an established goal, individually and as a team $[8,55,61]$. Additionally, they may prompt agencies, especially CM, closer to creating one organization with responsibility for the development of all involved entities and in an all-risk scenario pattern $[36,48,62]$, demonstrating practical, financial, and political advantages of such collaboration $[44,63]$.

One significant advantage of CM collaboration is what both organizations can learn from each other. The collaboration aims at generating the same goal and such partnership requires opportunities that enhance learning of each other's limitations and capabilities $[64,65]$, which also eases up and enables better resource and capacity sharing. The ideal collaboration should be developed through time $[29,66]$. Long-term development of such collaboration promotes and offers opportunities of creating one organization with responsibility for all development, education, and administration. Such an organization might be a necessity at the time of war and armed conflicts $[28,55,59,67,68]$ to address all aspects of collaboration, socially and politically and in several levels: nationally and internationally. Consequently, increasing the trust needed for implementing delicate measures and making crucial decisions $[41,42,69,70]$, without allowing one organization to be superior to the other $[43,71]$.

A mutual organization may additionally provide other important elements of relief operations, considering cultural and linguistic understanding, human rights promotion, community-based needs assessment, besides role identification, team working and communication $[28,47,55,59,72]$.

In summary, most publications emphasized the significance of the civilian-military partnership, prominently in how military support was incorporated in the national re- 
sponse, including support to national health systems, military repatriation and evacuation, and support to wider public systems. Additionally, the majority of studies suggest that collaborative educational initiatives in disaster medicine, public health and complex humanitarian emergencies, and international humanitarian law, along with advanced training in competency-based skill sets, should be included in the undergraduate education of health professionals. Finally, the most common CMC reported in the works of literature were in the fields of logistics and trauma. Other fields for CMC collaboration, e.g., infectious diseases, were poorly investigated [3,4,6-9,20-25,35,36,41-48,51-71,73,74].

\subsection{Survey Results}

A sum of 166 respondents answered the optimized questionnaires from the following 19 countries: Australia (2), Belgium (32), England (3), France (1), Germany (1), Greece (4), Iran (1), Italy (2), Israel (1), Mexico (1), Netherlands (3), Norway (3), Romania (8), Saudi Arabia (2), Sri Lanka (1), Sweden (11), Poland (80), Thailand (3), and the United Kingdom (3). Four respondents did not contribute their country of origin. All responses were sorted into four different groups for statistical analysis. Besides countries with over 10 participants (i.e., Belgium, Poland, and Sweden), all other nations, including responses with no country name, made up the fourth group called "others." Table 1 shows the age and gender distribution of all respondents. In total 128 respondents were physicians and 38 were other professionals, including nurses, psychologists, trainees, and strict military staff. The majority of participants were between 41-50 years of age, followed by 34 between 41-50 years of age, and 27 respondents with ages between $51-60$ years. The number of male participants was twice that of females.

Table 1. Shows the gender and age distribution of respondents in this study.

\begin{tabular}{cccccccccc}
\hline Respondents & Number & $\mathbf{< 3 0}$ & $\mathbf{3 1 - 4 0}$ & $\mathbf{4 1 - 5 0}$ & $\mathbf{5 1 - 6 0}$ & $\mathbf{> 6 0}$ & Phys. & Other & Mil \\
\hline Total & 166 & 19 & 40 & 52 & 32 & 23 & 128 & 38 & 20 \\
Female & 52 & 7 & 15 & 15 & 8 & 7 & 44 & 8 & 6 \\
Male & 114 & 12 & 25 & 37 & $\mathbf{2 4}$ & 16 & 84 & 30 & 14 \\
\hline
\end{tabular}

The collected results were analyzed using qualitative research methods. After identifying the thematic contents, they were categorized into core contents. The representative statements were outlined at a point where no novel information was retrieved from the data [75].

\subsection{Changes in CSCATTT}

For all respondents, there was an increase in the mean number of all CSCATTT dimensions under the COVID-19 pandemic. However, these changes were not statistically significant for any of the dimensions (Figure 2). Looking at the individual countries, none of the countries with more than 10 participants demonstrated any statistically significant increase in collaboration before and after the COVID-19 pandemic. Nevertheless, the results obtained solely from Belgium displayed a possible tendency toward significance in dimensions 2 (practical interface in command and control), 4 (safety and security), and 8 (transport). In Poland, only dimension 5 (communication and information), and in Sweden only dimension 1 (administrative part of command and control) showed a tendency to a significant increase.

Finally, the group called others did not demonstrate any statistically significant increase, although some of them such as the UK showed a very high numeric increase (Figure 2). 


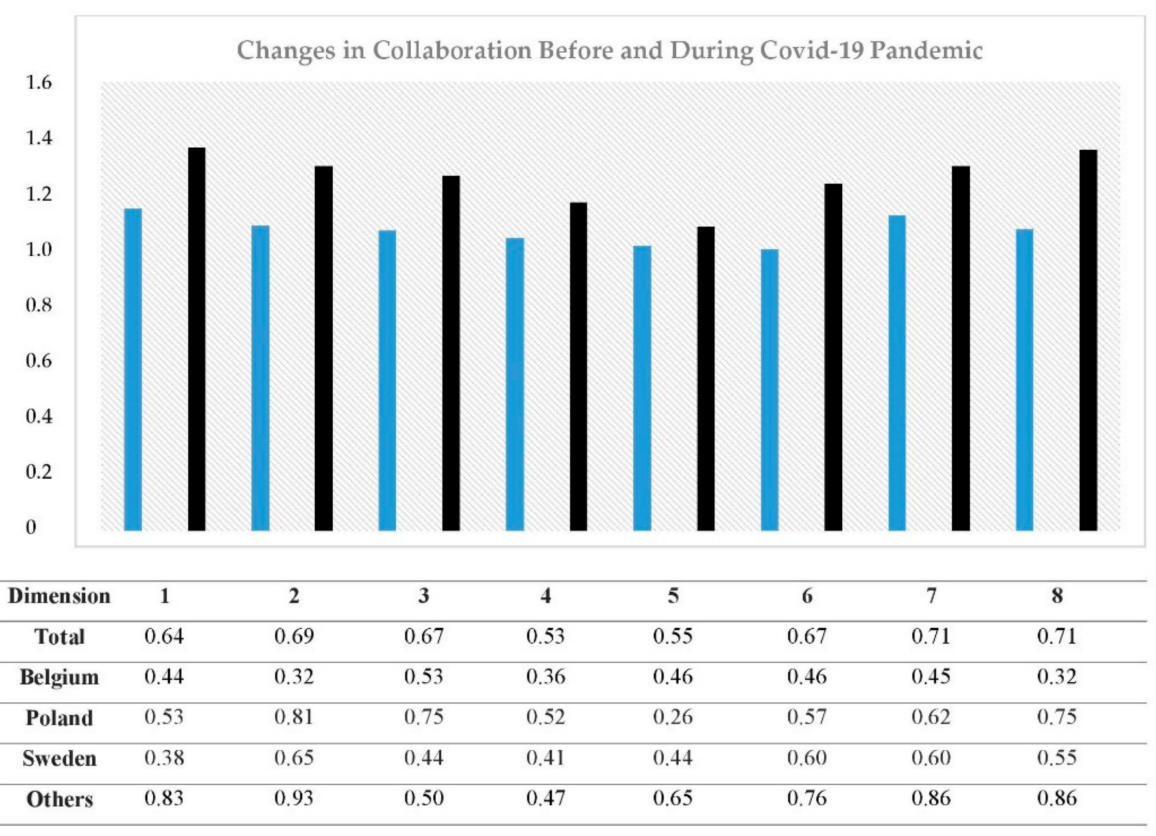

Figure 2. Shows the differences in collaboration before and during COVID-19 for all countries, and some specific countries with a larger number of participants displayed as mean. It also shows the $p$-value for each significant change (CI 95\%), where the light bars are the values before and darker (black bars) are values after the COVID-19 pandemic.

\subsection{Comments}

There were over 50 comments. All comments were grouped into four categories of No Collaboration $(29 / 49=59.2 \%)$, Some Collaboration $(12 / 49=24.5 \%)$, Full Collaboration $(3 / 49=6 \%)$, and others $(5 / 49=10.3 \%)$. In the latter group, two comments were technical and questionnaire-related (Table 2). Some of the comments were not about the subject but an expression of general dissatisfaction with slow progress in a specific country or the political interference with no results.

Table 2. Comments given by respondents were categorized into four groups.

No true collaboration.
Wo Changes.
We bad, now is worse. no help, no support.
I would say it is not better than it was. Before we could have at least some support (small but some)
and now there is no help. Of course not everywhere but in most healthcare facilities.
I see no big changes.
It is worse now.
Cooperation exists only in documents.
CM have plans we have big dreams and nothing has changed.
emergencies.
In my humble opinion, the collaboration between civil and military medical services is severely
lacking. A widely recognized and supported permanent collaboration platform would be ideal but, if it
even exists, it is lacking the prominent position it would deserve.
I think the current pandemic was a chance for better collaboration in clinical practice. The military is
the first to help in many areas just like in diagnostic or using a laboratory to support us. Did they do
this? No.


Table 2. Cont.

- I remember when we were in a communist system and there was integration with the civil sector. I was the first medic in the big division and we always support the local community. Thought the last years the potential of the medical background of the army was limited almost to zero. There are no people (MD) and stuff. The territorial defense force is one component of this system that might be useful during mass casualties and disasters. But, they are not trained. For now, there is no true collaboration and no support from the army. As a retired soldier, I am very disappointed due to this fact.

- CM collaboration is null during the pandemic. Rather strong logistics cooperation was implemented with the Civil Protection (of which I am part).

- No changes. It looked bad before and looks bad now. Maybe one in News they are talking about some great cooperation but there is nothing in reality.

- Cooperation only during major incidents. Or to show on TV.

- There were no CIMIC in XXX. Maybe some little support from TDF (Territorial defense force) is applied during disasters or emergencies but COVID did not bring anything new.

- Nothing has changed.

- It should be improved to get better results.

- Our expectation was verified by COVID. We could do much more but to politicians, the military was forced to do the stuff, which is not necessary. They should use them to help us in the way we need them. Not to be a guard.

- Before COVID, we at least have some meetings (rare) but now there is nothing.

- There is no real collaboration with the military in France, but with civil security. During COVID military offered help in some areas by transferring critical care patients from crowded regions to others less impacted by COVID.

- Lesson not learned. We could do much more but politicians (decisions) fail like always.

- Cooperation does not exist. There is also no longer any military health service. For example in the army, today there are 6 specialists in the field of emergency medicine. What can they do? Nobody wants to be in the army anymore. And the army is doing nothing for the civilian sector.

- Finally, we have guards at every entrance.

- CM Collaboration was disturbed by COVID. Military personnel was isolated to decrease the spread of the virus, through the CMC.

- There is no true CIMIC in XXX. The so-called Territorial defense, which is a more private gov army rather checks if we do our job instead of providing true help in the field we need.

- Failed by government.

- The northern part of XXXX has many mountains; patient transportations are usually needed through air transport. Therefore, hospitals in that part have very well collaboration.

- There are working protocols for air transportation with the military plane.

- The military was engaged to support the building of emergency surge capacity. This happened quickly and effectively, as per plans agreed beforehand.

- Improved compared to previous crisis (XXX attacks 2016)_implementation of Lessons Learned as soon as COVID crisis began.

- Besides, some small improvements with reporting which we can call communication, I do not see any changes.

- Only Communication has changed.

- Besides communication and some logistics support (if I can name being guard support) no big change.

- Some minor upgrades are applied but there is still a lot to do.

- Communication is improved. But, before COVID we have some annual meetings mostly with TDF.

Some collaboration Now there is no coordination. They (military) used to "help" as a guard, which could be done by local guards units.

- Some cooperation during COVID was observed but there were many actions that should never happen, i.e., monitoring hospitals by soldiers to check if we avoid patients.

- Some of these lay outside my field. However, there has since 2018, been an ongoing total-defense reform, and over the last 3-4 of years, while not directly during COVID, there have been examples of increased and well-functioning health CM collaboration during e.g., NATO collaboration exercises. There have also been examples of CM collaboration during COVID, but then more aimed towards border-control assistance.

- The Pandemic has brought a great understanding between military and civilian services, during the event. Logistic skills are always generally strong within the military.

- Before COVID, we haven't had much practical experience of CM collaboration. There wasn 't much during COVID either, but there was a clear ambition and progress. I find that the military part had more understanding for the civilian, compared to the opposite. My own experience and CM collaboration made my collaboration good (importance of network and understanding), but I found that several in my (civilian) organization lacked this. 
Table 2. Cont.

- Collaboration between civilians and the military in the medical field is strong before and during the COVID.

- Being engaged in 30 years of civil war, there has been a good CM collaboration as a necessity for

Full collaboration wartime military injury burden. However, before COVID, after the war, there was no pressing demand for CM collaboration. During the COVID, the ministry of health used military assets effectively by formulation of joint operational command comprising of both Director General Health Services and Commander to the Army.

- I have a long tradition of CM collaboration.

- Would be an easier answer if little examples were given.

- All questions should have a N/A (non-applicable) option.

- Big differences depending on the incidence of infections in the region of the hospital and the size of the hospital.

- To my knowledge, there are vast differences in both organizational cultures as well as planning and leadership methodology between civilian and military professions. To merge these two organizations

Others to a certain degree, there should first be a framework grounded in political consensus, which is lacking at present time. As long as this first crucial step is not agreed upon, there will be no long-lasting collaborative structures being built. Then and only then agencies of the state may find cooperative areas to endorse. There may be two ways to perform this: either through time-consuming legislation or by the foundation of a new state agency being the major responsible actor in this process.

- The question is whether the learning experiences are written down, followed up afterward, and included in CM educations so that better collaboration as well as improvements and better preparedness overall.

\section{Discussion}

Although the necessity of CMC in the management of evolving health crises has been reported and discussed in several publications [3,4,6,22-25,30-33,35,36], this study confirms the need and significance of CMC but fails to illustrate any significant improvement during the COVID-19 pandemic. The results from the survey may suggest possible improvements in some strategic areas, while the practical collaboration (e.g., training and operative engagement) remains missing or unchanged (e.g., logistics).

Theoretically, a successful CMC should encompass several perspectives, which are not completely visible during the current COVID-19 pandemic, globally, indicating that some nations may have a long way ahead to achieve an improved collaboration [16-18]. Although substantive outcomes and the more proficient use of resources represent a mutual target and may raise some awareness, there is still separate funding for both organizations and financial advantages might be a possible cause of collaboration. The current CMC may thus lack a political consensus and framework as cited by one of the participants;

Participants 1: To my knowledge, there are vast differences in both organizational culture as well as planning and leadership methodology between civilian and military professions. To merge these two organizations to a certain degree, there should first be a framework grounded in political consensus, which is lacking at present time. As long as this first crucial step is not agreed upon, there will be no long-lasting collaborative structures being built. Then and only then agencies of the state may find cooperative areas to endorse. There may be two ways to perform this: either through time-consuming legislation or by the foundation of a new state agency being the major responsible actor in this process.

There are different definitions of high productivity, probably due to diverse definitions of what collaboration is. The Oxford Dictionary [51] offers the following definitions: Collaboration is the act of working with another person or group of people to create or produce something. Cooperation is the fact of doing something together or of working together towards a shared aim. Finally, coordination is the act of making parts of something, groups of people, etc. work together in an efficient and organized way. While the literature seems to deal with reports of successful cooperation, few publications describe a unique production of CMC. 
Emergent milestones are partly lacking. There are some joint events but practical collaboration with a mutual target, when both organizations may share a benefit barely exist. In most cases, military healthcare assists the civilian partner; there might be a different outcome if civilian healthcare is asked to assist the military partner in an armed conflict while confronting a constrained system with overloaded emergency departments [59,72-74]. Several participants in the pilot survey expressed their views;

Participants 2: Communication has improved, but before COVID-19, we have some annual meetings. Now there is no coordination. They (military) used to "help" as a guard, which could be done by local guards' units.

There has been broad recognition of CMC during the current pandemic, mainly from strategic sources, while a few operational participants, in this study, declared their sincere pride to highlight their successful collaboration in a compatible organizational culture. Thus, affecting communication, trust, accountability, and consequently the outcomes of collaboration. As mentioned by Shanks Kaurin [19], civilian-military populations may share the same values but have a conflicting understanding of a situation, and different priorities while sharing the process, as cited below;

Participants 3: We have plans we have big dreams and nothing has changed.

Participants 4: In my humble opinion, the collaboration between civil and military medical services is severely lacking. A widely recognized and supported permanent collaboration platform would be ideal but, if it even exists, it is lacking the prominent position it would deserve.

The differences between participating countries in survey data may indicate a lack of unified definition, diverse social and historical background, and nation's involvement in earlier conflicts $[22,47,50,58,66,68]$. The prominent changes in this study were chiefly within the administration of the command-and-control section, while the logistics cooperation was unchanged. These coordinating and cooperative activities aim at achieving collaboration but may not necessarily target similar goals and outcomes [19].

Participants 5: Before COVID-19, we did not have much practical experience with CM collaboration. There wasn't much during COVID-19 either, but there was a clear ambition and progress. I find that the military part had more understanding for the civilian, compared to the opposite. My own experience and CM collaboration made my collaboration good (importance of the network and understanding), but I found that several in my (civilian) organization lacked this.

In some countries, e.g., Belgium, a mutual production of guidelines and instructions, safety and security considerations, communication and situational assessment, might indicate the first steps for a collaboration, however, defined by the Oxford Dictionary [51], achieving a collaboration, shared outcomes and goals, and establishing a control mechanism to ensure the operational outcome, are mandatory. Some countries with a few participants claimed a higher civilian-military collaboration level. The UK appears to be enjoying a fruitful and continuous interagency collaboration. Sri Lanka and Morocco also report prevailing collaboration between civilian and military healthcare systems. These successful collaborations may depend on previous involvement in international or national armed conflicts, which may necessitate such partnership or an apparent and continuous interest from the government. On the opposite, in countries such as Poland, there seems to be no trustful relationship between government and involved organizations, indicating the negative impacts of political interference in medical decision-making [27-29]. Nevertheless, there are not enough respondents from these countries to achieve a statistically significant result.

Participants 6: Being engaged in 30 years of civil war, there has been a good CM collaboration as a necessity for wartime military injury burden. However, before COVID19, after the war, there was no pressing demand for CM collaboration. During the COVID, the ministry of health used military assets effectively by formulation of joint operational 


\section{command comprising of both Director General Health Services and Commander to} the Army.

There are several essential factors for a successful partnership in disaster and emergency management. Factors such as relation-building focus on mutual learning and information sharing, bilateral and multilateral agreements, comprehending the concept of $\mathrm{CMC}$, trust, and mutual practical exercises, were all crucial elements of such partnership $[8,9,30,31,56-58,62]$. These conditions seem to be met in countries, such as the UK, while lacking in other European countries, such as Poland. A recent literature review, targeting six European countries reported that the most prominent partnership in these countries during COVID-19 consisted of incorporation of military support into the national COVID-19 response, e.g., support to national health and broader public systems, and military repatriation and evacuation [71], confirming the supportive role of the military in $\mathrm{CMC}$, but no real collaboration.

A fruitful CMC depends on organizations' mutual values, situational interpretations, priorities, processes and moral principles [2,22,63,74,76,77]. Since a fruitful and strong collaboration relies on a homogenous and synchronized relationship as well as compatible ethics, the goal in a collaboration should be having shared values and interpretation towards the same goal. The diverse responses from respondents included in this study regarding $\mathrm{CMC}$ dimensions indicate a difference between their perceptions compared to that of authorities, which also calls for the evaluation of ethical views in CMC. Firm leadership, collaboration, coordination, and decision-making are all crucial for planning, executing, and harmonizing all efforts needed for successful crisis management $[3,4,64,77]$. In opposition to previous studies, the current study may indicate that COVID-19 has offered new opportunities for a fruitful collaboration in command and control between military and civilian authorities [78-81]. Increasing administrative measures demand good communication to improve and enable situational awareness and assessment, resource distribution, technological development, practicing decision-making, and information sharing and provides new incentives for educational initiatives, and training [78,80,82]. An improved administrative meeting for mutual planning during the current pandemic inevitably has resulted in improved understanding of each other's abilities and shortcomings, issuing mutual documents and recommendations, and consequently an increase in partnership for smooth distribution of resources and logistics in some countries. While factors, such as a political will and unity, a trustful political-military-public relationship, transparency, and evidence-based approaches are necessary elements of any collaboration, collaboration should be practiced to allow all involved parties to realize their limitations and capabilities, practicing the crucial decision-making step in an environment where mistakes can be made with no harm $[1,2,4,22,29,41,83]$.

\section{Limitations}

One limitation to this study is the small number of respondents in the survey, necessitating a larger population study to achieve greater statistically significant results. The overwhelming majority of respondents came from two specific countries and given the uniqueness of civil-military relations in each country; the generalizability of such results is very limited. Diversities and peculiarities in cultures, national health systems, and CMC attitudes and experiences should be deeply inquired, and taken into strong account when testing and explaining CMC in different countries with diverse institutions.

Another limitation of the study was the use of English in the questionnaire and the search of the literature, which may have created some misunderstandings among participants and limited our search results, respectively.

Furthermore, there might be some doubts about using snowball sampling. However, the method has been used in several studies and is scientifically accepted. CMC may have a greater impact in larger nations with large militaries or in countries, which have built-in $\mathrm{CMC}$ into their medical infrastructures. However, even small countries such as Sweden 
without independent military healthcare seem to have a good collaboration, while larger countries such as Italy with different systems seem to have lost their routine partnership.

Finally, the use of coordination, cooperation, and collaboration in the literature to define the success and failure of CMC may have limited the results of the search. The use of a defined and united terminology is necessary for future publications.

\section{Recommendation}

- Define collaboration for future research and development.

- $\quad$ Create a trustful relationship between politic-public and profession (3P).

- Plan interaction through meetings, discussion, training, and practical work.

- Increase mutual research and teaching activities to increase the interest in CMC.

- Share information and educate the public to understand CMC.

- Create a mutual administrative activity or organization with similar goals and planning.

\section{Conclusions}

The COVID-19 pandemic has been associated with several changes and has revealed weaknesses and strengths in the current disaster and public health emergency management system, highlighting the importance of multiagency collaboration, particularly CMC. Although COVID-19 seems to have resulted in some progress in communication, coordination, resource distribution, and information sharing, there is still a need for stronger leadership, organizational closeness, and educational and training initiatives to guarantee a synchronized and well-functioning CMC. These steps are necessary to safeguard the practical partnership, operative management, harmony, and compatibility of CMC and require a political will and perhaps a mutual civilian-military authority.

Author Contributions: A.K.-M. provided the main framework, identified primary materials, and collaborated on the writing of the paper. K.G. organized research materials, identified appropriate references, and collaborated on the writing of the paper. A.K.-M., L.J.M., Y.R., F.M.B., and K.G. collaborated on the writing and editing of the paper. F.M.B. edited the final version. All authors have read and agreed to the published version of the manuscript.

Funding: This research received no external funding.

Institutional Review Board Statement: Not applicable.

Informed Consent Statement: Not applicable.

Data Availability Statement: Not applicable.

Conflicts of Interest: The authors declare no conflict of interest. 


\section{Appendix A}

\section{Health Evidence Helping public healthuse best evidence}

Instructions for completion:

Please refer to the attached dictionary for definition of terms and instructions for completing each section. For each criteria, score by placing a check mark in the appropriate box.
First Author:

Journal:

Reviewer:

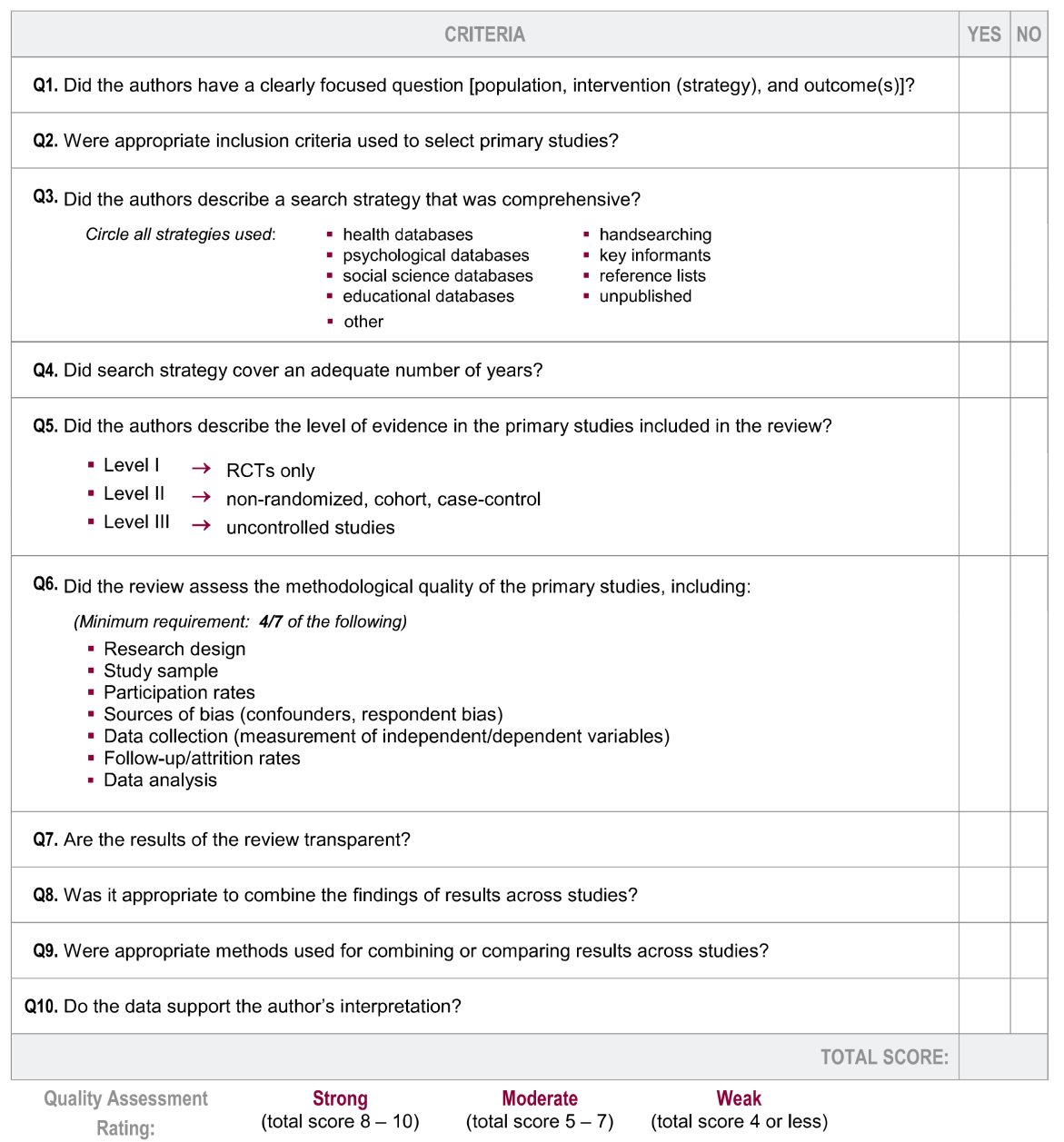

Figure A1. The protocol used for quality assessment of the included papers according to healthevidence.org, accessed on 14 June 2021. 


\section{Appendix B}

Table A1. Included and Evaluated studies; Title, Author, Year, Journal, Summary, Topic, Evidence.

\begin{tabular}{|c|c|c|c|c|c|c|c|}
\hline No & Title & $\begin{array}{c}\text { Author } \\
\text { (Ref No.) }\end{array}$ & Year & Journal & Summary & Topic & Evidence \\
\hline 1 & $\begin{array}{l}\text { Civilian military cooperation } \\
\text { strategies in developing new } \\
\text { technologies }\end{array}$ & $\begin{array}{l}\text { Kulve, } \\
\text { et al. [7] }\end{array}$ & 2003 & Research Pol & $\begin{array}{l}\text { This paper focuses on the cooperation between } \\
\text { civilian and military actors in developing new } \\
\text { technology, suggesting the establishment of } \\
\text { dual capacity networks, as part of a possible } \\
\text { strategy towards an integrated civilian-military } \\
\text { technology and industrial base. }\end{array}$ & $\begin{array}{l}\text { Co-operation, } \\
\text { strategic, tactical }\end{array}$ & M \\
\hline 2 & $\begin{array}{l}\text { A novel civilian-military } \\
\text { partnership in emergency } \\
\text { medical services during a } \\
\text { prolonged disaster: patient } \\
\text { characteristics, resources } \\
\text { utilization, and future } \\
\text { recommendations. }\end{array}$ & $\begin{array}{l}\text { Avegno, } \\
\text { et al. [31] }\end{array}$ & 2006 & Ann Emerg Med & $\begin{array}{l}\text { This study describes a civilian-military } \\
\text { partnership in the delivery of emergency } \\
\text { medical services (EMS) in a disaster area, } \\
\text { including medical needs, and resource } \\
\text { utilization of patients presenting to an EMS } \\
\text { unit in a prolonged disaster event and the } \\
\text { benefits of such a partnership for the staff } \\
\text { involved and the community at large. }\end{array}$ & $\begin{array}{c}\text { Co-operation at all } \\
\text { levels }\end{array}$ & $S$ \\
\hline 3 & $\begin{array}{l}\text { Civilian-military coordination in } \\
\text { emergency response in } \\
\text { Indonesia }\end{array}$ & $\begin{array}{l}\text { Joyce, } \\
\text { et al. [6] }\end{array}$ & 2006 & Mil Med & $\begin{array}{l}\text { Specific events and activities illustrate the } \\
\text { comparative roles of civilian and military } \\
\text { organizations and the importance of } \\
\text { recognition of each organization's abilities and } \\
\text { limitations. }\end{array}$ & Coordination & M \\
\hline 4 & $\begin{array}{l}\text { A Review of Nurses in Disaster } \\
\text { Preparedness and Response: } \\
\text { Military \& Civilian } \\
\text { Collaboration. }\end{array}$ & $\begin{array}{l}\text { Rivers, } \\
\text { et al. [23] }\end{array}$ & 2010 & JHSEM & $\begin{array}{l}\text { This review of the literature provides an } \\
\text { overview and reveals some of the difficulties } \\
\text { and lessons learned from civilian-military } \\
\text { coordination over time. }\end{array}$ & $\begin{array}{l}\text { Cooperation, } \\
\text { strategic, tactical } \\
\text { levels, and research }\end{array}$ & $S$ \\
\hline 5 & $\begin{array}{l}\text { Pandemic Influenza } \\
\text { preparedness and response in } \\
\text { Israel: A unique model of } \\
\text { civilian-military collaboration }\end{array}$ & Kohn, et al. [45] & 2010 & JPHP & $\begin{array}{l}\text { Discussing pandemics and pandemic } \\
\text { preparedness protocols as a collaboration tool } \\
\text { in medical decision-making within the defense } \\
\text { sector. Although not generalizable, it offers a } \\
\text { unique forum for all agencies to evaluate this } \\
\text { interface within the context of pandemic } \\
\text { influenza. }\end{array}$ & $\begin{array}{c}\text { Strategic } \\
\text { collaboration }\end{array}$ & M \\
\hline
\end{tabular}


Table A1. Cont.

\begin{tabular}{|c|c|c|c|c|c|c|c|}
\hline No & Title & $\begin{array}{l}\text { Author } \\
\text { (Ref No.) }\end{array}$ & Year & Journal & Summary & Topic & Evidence \\
\hline 6 & $\begin{array}{l}\text { Collaboration between civilian } \\
\text { and military healthcare } \\
\text { professionals: a better way for } \\
\text { planning, preparing, and } \\
\text { responding to all-hazard } \\
\text { domestic events }\end{array}$ & Marklund, et al. [30] & 2010 & $\begin{array}{l}\text { Prehosp Disaster } \\
\text { Med }\end{array}$ & $\begin{array}{l}\text { This review summarizes the long and rich } \\
\text { history of collaboration between civilians and } \\
\text { the military in various countries and provides } \\
\text { support for the continuation and improvement } \\
\text { of collaborative efforts. }\end{array}$ & Collaboration & M \\
\hline 7 & $\begin{array}{l}\text { Civilian Military Cooperation in } \\
\text { crisis management in Africa: } \\
\text { American and European union's } \\
\text { policy compared. }\end{array}$ & $\begin{array}{l}\text { Olsen, } \\
\text { et al. [24] }\end{array}$ & 2011 & J Int Rel Dev & $\begin{array}{l}\text { This paper discusses the need for widespread } \\
\text { consensus among various actors, necessary to } \\
\text { combine civilian and military instruments in } \\
\text { crisis management. }\end{array}$ & $\begin{array}{c}\text { Strategic and } \\
\text { Cooperative models }\end{array}$ & M \\
\hline 8 & $\begin{array}{l}\text { Using the military in disaster } \\
\text { relief: systemizing challenges } \\
\text { and opportunities }\end{array}$ & $\begin{array}{l}\text { Heaslip, } \\
\text { et al. [46] }\end{array}$ & 2014 & $\begin{array}{l}\text { J Human Log Supply } \\
\text { Chain Manag }\end{array}$ & $\begin{array}{l}\text { Discusses the challenges of civil- military } \\
\text { logistical cooperation, coordination, and } \\
\text { collaboration in humanitarian relief logistics. }\end{array}$ & $\begin{array}{l}\text { Coordination, } \\
\text { cooperation, } \\
\text { collaboration at } \\
\text { operational level, } \\
\text { Research }\end{array}$ & $\mathrm{S}$ \\
\hline 9 & $\begin{array}{l}\text { Role clarity, swift trust, and } \\
\text { multi-agency coordination. }\end{array}$ & Curnin, et al. [9] & 2015 & $\begin{array}{l}\text { J Conting Crisis } \\
\text { Manag }\end{array}$ & $\begin{array}{l}\text { Discuss the importance of swift trust and role } \\
\text { clarity in temporary organizations during } \\
\text { emergency management coordination. }\end{array}$ & $\begin{array}{l}\text { Coordination } \\
\text { Research }\end{array}$ & M \\
\hline 10 & $\begin{array}{l}\text { The Best of Both Worlds: } \\
\text { Psychiatry Training at } \\
\text { Combined Civilian-Military } \\
\text { Programs. }\end{array}$ & $\begin{array}{l}\text { Welton, } \\
\text { et al. [25] }\end{array}$ & 2015 & Acad Psych & $\begin{array}{l}\text { Discuss the role of collaboration in creating } \\
\text { hybrid-training programs in Psychiatry. }\end{array}$ & $\begin{array}{l}\text { Educational } \\
\text { Strategic tactical } \\
\text { Cooperation and } \\
\text { coordination }\end{array}$ & M \\
\hline 11 & $\begin{array}{l}\text { Military-civilian cooperative } \\
\text { emergency response to } \\
\text { infectious disease prevention } \\
\text { and control in China }\end{array}$ & $\begin{array}{l}\text { Ma, } \\
\text { et al. [57] }\end{array}$ & 2016 & Mil Med Res & $\begin{array}{l}\text { The Chinese CMC in management of infectious } \\
\text { disease prevention and control, focusing on } \\
\text { mechanisms in several levels and stages like } \\
\text { the military-cooperative emergency response to } \\
\text { infectious diseases -the joint working } \\
\text { mechanism, the information-sharing } \\
\text { mechanism, the research collaboration } \\
\text { mechanism, and the joint disposal } \\
\text { mechanism-and presents a sorted summary of } \\
\text { the practices and experiences of cooperative } \\
\text { emergency responses to infectious diseases. }\end{array}$ & All level Cooperation & M \\
\hline
\end{tabular}


Table A1. Cont.

\begin{tabular}{|c|c|c|c|c|c|c|c|}
\hline No & Title & $\begin{array}{l}\text { Author } \\
\text { (Ref No.) }\end{array}$ & Year & Journal & Summary & Topic & Evidence \\
\hline 12 & $\begin{array}{l}\text { Military and Civilian } \\
\text { Collaboration: The Power of } \\
\text { Numbers }\end{array}$ & $\begin{array}{l}\text { Stinner, } \\
\text { et al. [32] }\end{array}$ & 2017 & Mil Med & $\begin{array}{l}\text { Compare the number and types of extremity } \\
\text { injuries treated at civilian trauma centers vs. } \\
\text { military treatment facilities and investigate the } \\
\text { potential benefits of a clinical research network } \\
\text { that includes both civilian trauma centers and } \\
\text { military trauma facilities. }\end{array}$ & $\begin{array}{l}\text { Coordination } \\
\text { Cooperation }\end{array}$ & M \\
\hline 13 & $\begin{array}{l}\text { Military-Civilian Collaborations } \\
\text { for mTBI Rehabilitation } \\
\text { Research in an Active Duty } \\
\text { Population: Lessons Learned } \\
\text { From the Assessment of Military } \\
\text { Multitasking Performance } \\
\text { Project }\end{array}$ & McCulloch, et al. [33] & 2017 & $\begin{array}{l}\text { J Head Trauma } \\
\text { Rehab }\end{array}$ & $\begin{array}{l}\text { This article describes lessons learned in the } \\
\text { planning, development, and administration of } \\
\text { a collaborative military-civilian research } \\
\text { project, the Assessment of Military } \\
\text { Multitasking Performance. }\end{array}$ & $\begin{array}{l}\text { Strategic, Tactical } \\
\text { Collaboration } \\
\text { Research }\end{array}$ & M \\
\hline 14 & $\begin{array}{l}\text { Non-Medical aspects of } \\
\text { civilian-military collaboration in } \\
\text { the management of major } \\
\text { incidents. }\end{array}$ & $\begin{array}{l}\text { Khorram-Manesh, } \\
\text { et al. [3] }\end{array}$ & 2017 & $\begin{array}{c}\text { Eur J Trauma Emerg } \\
\text { Surg }\end{array}$ & $\begin{array}{l}\text { The paper builds up a discussion about } \\
\text { civilian-military collaboration by presenting } \\
\text { the result of simulation training. }\end{array}$ & $\begin{array}{l}\text { Simulation and } \\
\text { Education all level } \\
\text { Collaboration }\end{array}$ & $S$ \\
\hline 15 & $\begin{array}{l}\text { Obstacles to civil-military } \\
\text { collaboration in conflict zones } \\
\text { when organizations go to war }\end{array}$ & Leprince, C. [58] & 2017 & $\begin{array}{c}\text { Etudes } \\
\text { Internationales }\end{array}$ & $\begin{array}{l}\text { Discussed the reasons for organizational } \\
\text { tensions The results shed new light on the } \\
\text { study of civil-military cooperation and yield } \\
\text { policy lessons for optimizing Canada's } \\
\text { international interventions. }\end{array}$ & $\begin{array}{l}\text { Research, } \\
\text { Strategic-Tactical } \\
\text { Cooperation }\end{array}$ & M \\
\hline 16 & The military partnerships & Brandt. [59] & 2017 & $\begin{array}{c}\text { J Trauma Acute Care } \\
\text { Surg }\end{array}$ & $\begin{array}{l}\text { Expanding the mission of all of the Military } \\
\text { Treatment Facilities (MTF) in the United States } \\
\text { to include the medical care of the poor and } \\
\text { disadvantaged patients in those communities. } \\
\text { To expand the civilian/military collaboration } \\
\text { beyond trauma care to maintain competency } \\
\text { and readiness of all military medical personnel } \\
\text { in war and peace. In war and disaster relief, in } \\
\text { addition to the care of service members, the } \\
\text { military medical professionals often care for the } \\
\text { local population. }\end{array}$ & $\begin{array}{c}\text { Operative } \\
\text { collaboration } \\
\text { Strategic planning }\end{array}$ & $\mathrm{w}$ \\
\hline
\end{tabular}


Table A1. Cont.

\begin{tabular}{|c|c|c|c|c|c|c|c|}
\hline No & Title & $\begin{array}{l}\text { Author } \\
\text { (Ref No.) }\end{array}$ & Year & Journal & Summary & Topic & Evidence \\
\hline 17 & $\begin{array}{l}\text { Civilian-military pooling of } \\
\text { health care resources in Haiti: a } \\
\text { theory of complementarities } \\
\text { perspective: The Swedish } \\
\text { perspectives. }\end{array}$ & Naor [35] & 2018 & Int J Product Res & $\begin{array}{l}\text { This study investigates opportunities and } \\
\text { barriers for relief organizations to pool } \\
\text { complementary resources originating from } \\
\text { multiple countries, by examining five case } \\
\text { studies that represent the breadth of } \\
\text { organizational types, including charter (civilian, } \\
\text { military, university-affiliated. and } \\
\text { public/private), facility type (primary, secondary, } \\
\text { and tertiary care), and duration of stay. }\end{array}$ & $\begin{array}{c}\text { Research and } \\
\text { Education, Strategic } \\
\text { planning }\end{array}$ & M \\
\hline 18 & $\begin{array}{l}\text { Facilitators and constrainers of } \\
\text { civilian-military collaboration. }\end{array}$ & $\begin{array}{l}\text { Khorram-Manesh, } \\
\text { et al. [4] }\end{array}$ & 2018 & $\begin{array}{l}\text { Eur J Trauma Emerg } \\
\text { Surg }\end{array}$ & $\begin{array}{l}\text { The paper discusses how the current global } \\
\text { and domestic security threats and challenges } \\
\text { make CMC critical and inevitable. However, } \\
\text { there is a need for careful analysis of its } \\
\text { consequences, impact, possibilities, and } \\
\text { limitations to differentiate between our } \\
\text { expectations and the current reality. }\end{array}$ & $\begin{array}{c}\text { Operative } \\
\text { Collaboration } \\
\text { Strategic Planning }\end{array}$ & M \\
\hline 20 & $\begin{array}{l}\text { Characterizing the importance } \\
\text { of clarity of roles and } \\
\text { responsibilities in government } \\
\text { inter-organizational } \\
\text { collaboration and information } \\
\text { sharing initiatives. }\end{array}$ & Gil-Garcia, et al. [8] & 2019 & Gov Info Quarter & $\begin{array}{l}\text { Further discussion about three significant } \\
\text { determinants of Clarity of Roles and } \\
\text { Responsibility in Cross-Boundary Information } \\
\text { Sharing, namely (1) the extent participants use } \\
\text { boundary objects, (2) participant skills in terms } \\
\text { of collaboration, coordination, and } \\
\text { communication, and (3) the diversity of the } \\
\text { participating organizations and their goals. }\end{array}$ & $\begin{array}{l}\text { Coordination } \\
\text { Cooperation } \\
\text { Collaboration } \\
\text { Research }\end{array}$ & M \\
\hline
\end{tabular}


Table A1. Cont.

\begin{tabular}{|c|c|c|c|c|c|c|c|}
\hline No & Title & $\begin{array}{l}\text { Author } \\
\text { (Ref No.) }\end{array}$ & Year & Journal & Summary & Topic & Evidence \\
\hline 21 & $\begin{array}{l}\text { Immediate response to major } \\
\text { incidents: defining an } \\
\text { immediate responder! }\end{array}$ & $\begin{array}{l}\text { Khorram-Manesh, } \\
\text { et al. [56] }\end{array}$ & 2019 & $\begin{array}{l}\text { Eur J Trauma Emerg } \\
\text { Surg }\end{array}$ & $\begin{array}{l}\text { This paper discusses the use of civilians and } \\
\text { immediate responders in MCI and concludes } \\
\text { that the use of immediate responders is a } \\
\text { life-saving approach in MCIs and situations } \\
\text { when every minute counts and every human } \\
\text { resource is an invaluable asset. }\end{array}$ & $\begin{array}{l}\text { Strategic, operative } \\
\text { planning for civilian } \\
\text { preparedness. }\end{array}$ & M \\
\hline 22 & $\begin{array}{l}\text { Implementation and Evaluation } \\
\text { of a Military-Civilian } \\
\text { Partnership to Train Mental } \\
\text { Health Specialists }\end{array}$ & $\begin{array}{l}\text { Simpson, } \\
\text { et al. [62] }\end{array}$ & 2019 & Mil Med & $\begin{array}{l}\text { The study describes a novel military-civilian } \\
\text { collaboration in training. }\end{array}$ & $\begin{array}{l}\text { Training, } \\
\text { Educational, strategic } \\
\text { planning for } \\
\text { collaboration }\end{array}$ & M \\
\hline 23 & $\begin{array}{l}\text { The Territorial Defence Force in } \\
\text { Disaster Response in Poland: } \\
\text { Civil-Military Collaboration } \\
\text { during the State of Emergency }\end{array}$ & Goniewicz, et al. [48] & 2019 & Sustainability & $\begin{array}{l}\text { The recreation of the existing Polish Territorial } \\
\text { Defense Force in disaster-related missions, } \\
\text { limited to the territory of the country and } \\
\text { largely focused on cooperation with the civilian } \\
\text { sector. }\end{array}$ & $\begin{array}{l}\text { Strategic, tactical, } \\
\text { and operative } \\
\text { cooperation }\end{array}$ & M \\
\hline 24 & $\begin{array}{l}\text { A short report on an } \\
\text { interprofessional mobilizer team: } \\
\text { innovation and impact during } \\
\text { the COVID-19 pandemic. }\end{array}$ & $\begin{array}{l}\text { Stifter, } \\
\text { et al. [36] }\end{array}$ & 2020 & J Int Prof Care & $\begin{array}{l}\text { Inter-professional collaboration is an integral } \\
\text { component when implementing a robust and } \\
\text { comprehensive response to crises. }\end{array}$ & $\begin{array}{l}\text { Strategic, tactical, } \\
\text { and operational } \\
\text { collaboration }\end{array}$ & M \\
\hline 25 & $\begin{array}{l}\text { Rapid Response: } \\
\text { Civilian-military medical } \\
\text { collaboration-an everyday } \\
\text { medical implementation? }\end{array}$ & Mitchel, [44] & 2020 & $\mathrm{BMJ}$ & $\begin{array}{l}\text { Short comments about various practical, } \\
\text { financial, and political pros and cons to } \\
\text { integrating civilian-military collaboration into } \\
\text { everyday medical practice, but following the } \\
\text { eventual passing of this pandemic, isn't it } \\
\text { worth considering its medical role in more than } \\
\text { simply major incident response? }\end{array}$ & Strategic, Planning & $\mathrm{W}$ \\
\hline 26 & $\begin{array}{l}\text { Developing a blueprint for a } \\
\text { civilian-military collaborative } \\
\text { program in trauma training for } \\
\text { Northern European countries: A } \\
\text { South African experience }\end{array}$ & $\begin{array}{l}\text { van der Wal, et al. } \\
{[64]}\end{array}$ & 2020 & Injury & $\begin{array}{l}\text { To describe and create a collaborative program } \\
\text { between a major South African trauma service } \\
\text { and a NATO country military medical service, } \\
\text { with a synergistic effect on both partners. }\end{array}$ & $\begin{array}{l}\text { Training, education, } \\
\text { strategic planning for } \\
\text { collaboration }\end{array}$ & M \\
\hline
\end{tabular}


Table A1. Cont.

\begin{tabular}{|c|c|c|c|c|c|c|c|}
\hline No & Title & $\begin{array}{l}\text { Author } \\
\text { (Ref No.) }\end{array}$ & Year & Journal & Summary & Topic & Evidence \\
\hline 27 & $\begin{array}{l}\text { Flexible surge capacity_Public } \\
\text { health, public education, and } \\
\text { disaster management. }\end{array}$ & $\begin{array}{c}\text { Khorram-Manesh, } \\
{[60]}\end{array}$ & 2020 & Health Pro Pers & $\begin{array}{l}\text { This study evaluates the concept of surge } \\
\text { capacity, which intends to achieve a balance } \\
\text { between the needs and resources in affected } \\
\text { areas by providing staff, stuff, structure, and } \\
\text { system and enhancing multiagency } \\
\text { cooperation, coordination, and collaboration. }\end{array}$ & $\begin{array}{l}\text { Coordination, } \\
\text { cooperation, and } \\
\text { collaboration }\end{array}$ & M \\
\hline 28 & $\begin{array}{l}\text { Pilot study of a longitudinal } \\
\text { integrated disaster and military } \\
\text { medicine education program for } \\
\text { undergraduate medical students }\end{array}$ & Tsai, et al. [65] & 2020 & Medicine & $\begin{array}{l}\text { The need for understanding disaster medicine } \\
\text { and the health care system during massive } \\
\text { casualty incidents is an integral part of the } \\
\text { medical curriculum. }\end{array}$ & $\begin{array}{l}\text { Educational, } \\
\text { strategic, and tactical } \\
\text { planning }\end{array}$ & M \\
\hline 29 & $\begin{array}{l}\text { Military Planning. What the } \\
\text { NHS is learning from the British } \\
\text { army in the COVID- } 19 \text { crisis. }\end{array}$ & Watts, et al. [66] & 2020 & BMJ & $\begin{array}{l}\text { Short discussion regarding how the civilian } \\
\text { part can learn from the military side by } \\
\text { considering some factors; Planning not plans, } \\
\text { Speed and scale, and Chain of commands. }\end{array}$ & $\begin{array}{l}\text { Strategic, } \\
\text { Planning }\end{array}$ & $\mathrm{W}$ \\
\hline 30 & $\begin{array}{l}\text { Swedish Emergency Hospitals } \\
\text { surgical surge capacity to mass } \\
\text { casualty incidents. }\end{array}$ & $\begin{array}{l}\text { Blimark, } \\
\text { et al. [29] }\end{array}$ & 2020 & SJTREM & $\begin{array}{l}\text { This paper discusses the preparedness in } \\
\text { Swedish hospitals and their capacity during MCI } \\
\text { and concludes that the MCI preparedness of } \\
\text { Swedish emergency care hospitals needs further } \\
\text { attention. To improve Swedish surgical MCI } \\
\text { preparedness a national strategy for trauma care } \\
\text { in disaster management is necessary. }\end{array}$ & $\begin{array}{l}\text { Strategic, tactical, } \\
\text { and operational } \\
\text { planning }\end{array}$ & $\mathrm{W}$ \\
\hline 31 & $\begin{array}{l}\text { The History of Swedish Military } \\
\text { Healthcare System and Its Path } \\
\text { Toward Civilian-Military } \\
\text { Collaboration from a Total } \\
\text { Defense Perspective. }\end{array}$ & $\begin{array}{c}\text { Khorram-Manesh, } \\
\text { et al. [67] }\end{array}$ & 2020 & MilMed & $\begin{array}{l}\text { This paper discusses the historical } \\
\text { development of military medicine and the need } \\
\text { for civilian-military collaboration from a } \\
\text { Swedish perspective and concludes that the } \\
\text { Swedish concept of total defense's healthcare } \\
\text { system integration and collaboration may be a } \\
\text { more fruitful approach. The collaboration } \\
\text { within the total defense healthcare system will } \\
\text { result in technical achievements, innovations, } \\
\text { and medical advancements for the benefit of } \\
\text { the whole nation. }\end{array}$ & $\begin{array}{l}\text { Strategic, tactical, } \\
\text { and operational } \\
\text { planning }\end{array}$ & M \\
\hline
\end{tabular}


Table A1. Cont.

\begin{tabular}{|c|c|c|c|c|c|c|c|}
\hline No & Title & $\begin{array}{l}\text { Author } \\
\text { (Ref No.) }\end{array}$ & Year & Journal & Summary & Topic & Evidence \\
\hline 32 & $\begin{array}{l}\text { Use of military forces in the } \\
\text { COVID-19 emergency. }\end{array}$ & Cancian. [63] & 2020 & Web CSIS & $\begin{array}{l}\text { This analysis addresses the distinctive roles of } \\
\text { U.S. federal military forces and state National } \\
\text { Guard units, the ways U.S. forces could be } \\
\text { most helpful, the limitations on military forces, } \\
\text { and the potential cost of employing the military } \\
\text { to help fight the coronavirus. }\end{array}$ & $\begin{array}{l}\text { Strategic planning for } \\
\text { Cooperation }\end{array}$ & $\mathrm{W}$ \\
\hline 33 & $\begin{array}{l}\text { Total Defence Resilience: Viable } \\
\text { or Not During COVID-19? A } \\
\text { Comparative Study of Norway } \\
\text { and the UK. Risk Hazards Crisis } \\
\text { Public Policy. }\end{array}$ & Pollock et al. [68] & 2020 & $\begin{array}{l}\text { Risk Haz Crisis } \\
\text { Public Policy }\end{array}$ & $\begin{array}{l}\text { Studying the application of total defense (TD) } \\
\text { during the COVID-19 crisis and exploring what } \\
\text { makes the TD a viable system with resilience } \\
\text { capabilities in the face of the crisis by } \\
\text { comparing British and Norwegian TD systems. }\end{array}$ & $\begin{array}{l}\text { Strategic and } \\
\text { research-based } \\
\text { description for } \\
\text { Collaborative actions }\end{array}$ & M \\
\hline 34 & $\begin{array}{l}\text { How do we fight COVID-19? } \\
\text { Military medical actions in the } \\
\text { war against the COVID-19 } \\
\text { pandemic in France. }\end{array}$ & $\begin{array}{l}\text { Pasquier, } \\
\text { et al. [69] }\end{array}$ & 2020 & BMJ & $\begin{array}{l}\text { Presenting multiagency collaboration in France } \\
\text { as well as overseas. }\end{array}$ & $\begin{array}{l}\text { Strategic, tactical } \\
\text { Collaboration }\end{array}$ & M \\
\hline 35 & $\begin{array}{l}\text { Pandemics meet democracy: } \\
\text { Experimental evidence from the } \\
\text { COVID-19 crisis in Spain. }\end{array}$ & $\begin{array}{l}\text { Amat, } \\
\text { et al. [41] }\end{array}$ & 2020 & arXiv & $\begin{array}{l}\text { The results of a set of survey experiments in } \\
\text { Spain together with longitudinal evidence from } \\
\text { a panel survey fielded right before and after the } \\
\text { virus outbreak. }\end{array}$ & $\begin{array}{l}\text { Experts, Opinion, } \\
\text { Civilian, } \\
\text { Collaboration }\end{array}$ & S \\
\hline 36 & $\begin{array}{l}\text { The effect of COVID-19 } \\
\text { lockdowns on political support: } \\
\text { Some good news for } \\
\text { democracy? }\end{array}$ & Bol, et al. [42] & 2020 & Eur J Politic Res & $\begin{array}{l}\text { A web-based survey in Western Europe to } \\
\text { compare the political support of those who } \\
\text { took the survey right before and right after the } \\
\text { start of the lockdown in their country. }\end{array}$ & $\begin{array}{l}\text { Opinion, Civilian, } \\
\text { Collaborative, } \\
\text { Strategic planning }\end{array}$ & M \\
\hline 37 & $\begin{array}{l}\text { Civilian perception of the role in } \\
\text { Nigeria's } 2014 \text { Ebola outbreak } \\
\text { and health-related responses in } \\
\text { the North East region }\end{array}$ & $\begin{array}{l}\text { Kwaja, } \\
\text { et al. [47] }\end{array}$ & 2021 & BMJ Mil Health & $\begin{array}{l}\text { Robust civilian-military relations require an } \\
\text { appropriately defined role of the military and } \\
\text { clear communication. Some important } \\
\text { considerations include military } \\
\text { cultural-linguistic understanding, human } \\
\text { rights promotion, and community-based needs } \\
\text { assessments; such foci can facilitate the } \\
\text { military's understanding of community norms } \\
\text { and civilian cooperation with military aims. }\end{array}$ & $\begin{array}{l}\text { Opinion, Strategic, } \\
\text { tactical all level } \\
\text { Collaboration }\end{array}$ & M \\
\hline
\end{tabular}


Table A1. Cont.

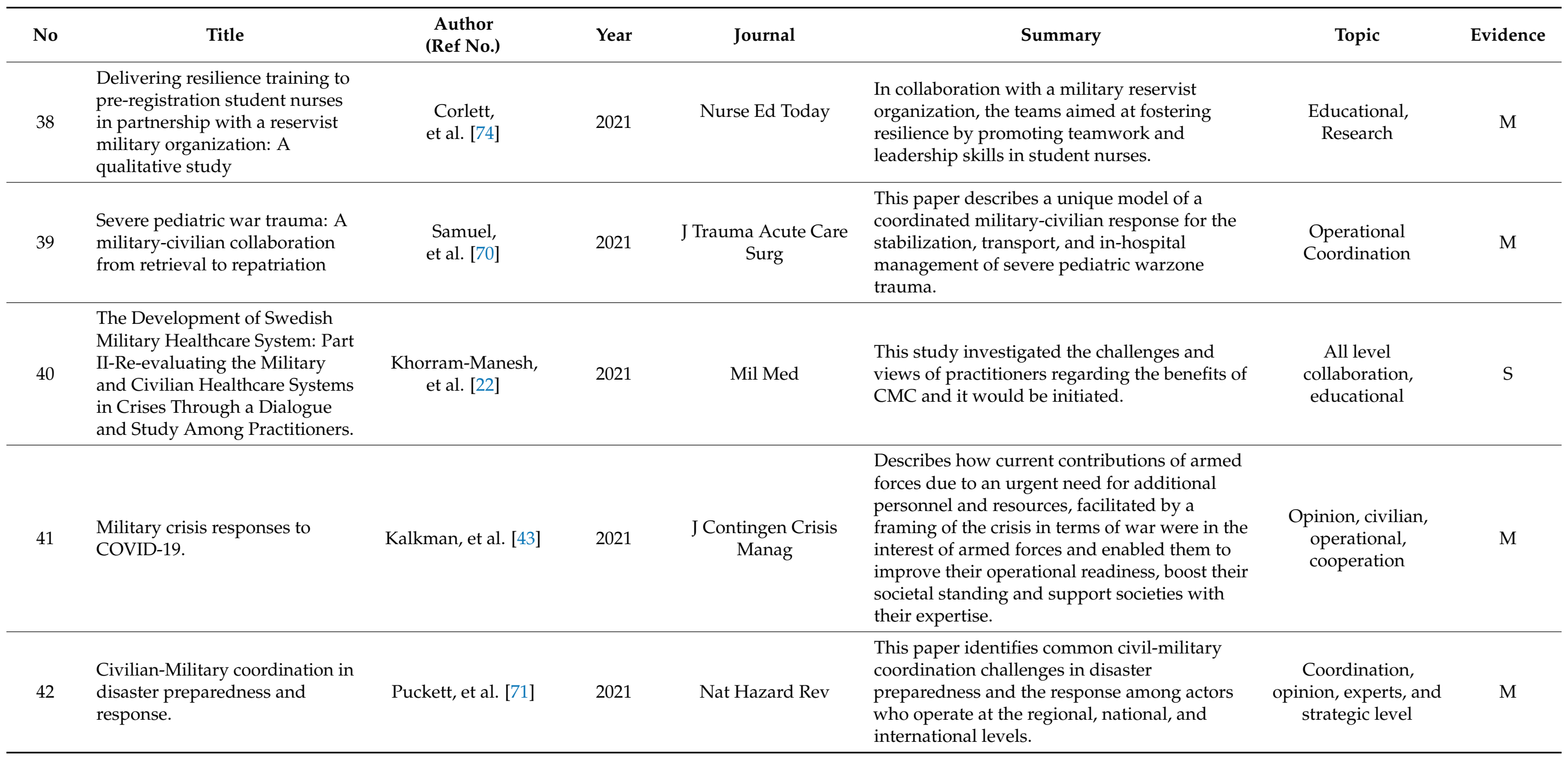


Table A1. Cont.

\begin{tabular}{|c|c|c|c|c|c|c|c|}
\hline No & Title & $\begin{array}{l}\text { Author } \\
\text { (Ref No.) }\end{array}$ & Year & Journal & Summary & Topic & Evidence \\
\hline 43 & $\begin{array}{l}\text { Civil-military cooperation in the } \\
\text { early response to the COVID-19 } \\
\text { pandemic in six European } \\
\text { countries. }\end{array}$ & Gad, et al. [72] & 2021 & BMJ Mil Health & $\begin{array}{l}\text { This qualitative literature review targeted six } \\
\text { European countries and found } 19 \text { distinct } \\
\text { descriptive categories of civil-military } \\
\text { cooperation extending across seven analytical } \\
\text { themes of which the most prominent included } \\
\text { how military support was incorporated in the } \\
\text { national COVID-19 response, e.g., support to } \\
\text { national health systems, military repatriation, } \\
\text { and evacuation, and support to wider public } \\
\text { systems. }\end{array}$ & $\begin{array}{l}\text { Cooperation, } \\
\text { support, repatriation, } \\
\text { public system } \\
\text { support }\end{array}$ & $\mathrm{M}$ \\
\hline
\end{tabular}




\section{Appendix C The Questionnaire Introduction}

Civilian-Military Collaboration (CMC) is desired for the successful management of emergencies, disasters, and pandemics. This short survey aims to identify differences between two periods, BEFORE and DURING COVID-19 pandemic.

By conducting this survey, you agree to participate voluntarily. No name, affiliation, or other searchable information, but your profession and civilian/military status are registered. The data is handled in strict confidentiality and secure data storage and the study complies with the ethical principles stipulated by Swedish law, SFS 2008:192 and SFS 2003:460.

Please choose one of the options below, as indicated on the Likert Scale, for each question before and during the current COVID-19 pandemic in the table.

1: Weak 2: Fair 3: Undecided 4: Good 5: Strong

You may provide an example if needed. Comments are welcomed.

General information

A. Country: B. Gender: C. Profession: D. Civilian/Military E. Age: under 30 31-40 $41-5051-60>60$

\begin{tabular}{|c|c|c|c|}
\hline No. & Questions/Dimensions & during & CSCATTT \\
\hline 1 & $\begin{array}{l}\mathrm{CMC} \text {, defined as the overall assessment of meetings and planning } \\
\text { regarding healthcare issues. }\end{array}$ & & $\begin{array}{l}\text { Command and control } \\
\text { (administrative) }\end{array}$ \\
\hline 2 & $\begin{array}{l}\mathrm{CMC} \text {, defined as the overall assessment of practical interferences regarding } \\
\text { healthcare issues. }\end{array}$ & & $\begin{array}{l}\text { Command and control } \\
\text { (practical) }\end{array}$ \\
\hline 3 & $\begin{array}{l}\text { The practical implementation of } \mathrm{CM} \text { mutual decisions, defined as the } \\
\text { overall assessment of mutual directives, recommendations, and plans. }\end{array}$ & & $\begin{array}{l}\text { Command and control } \\
\text { (Mutual guidelines) }\end{array}$ \\
\hline 4 & $\begin{array}{l}\text { CMC and coordination of safety issues, defined as an overall assessment of } \\
\text { sharing information, knowledge, and items such as protective equipment. }\end{array}$ & & Safety, Security \\
\hline 5 & $\begin{array}{l}\text { CMC, defined as the overall assessment of contacts, meetings, and sharing } \\
\text { communication systems. }\end{array}$ & & $\begin{array}{l}\text { Communication, } \\
\text { Information }\end{array}$ \\
\hline 6 & $\begin{array}{l}\text { The mutual assessment of the incident/situation, defined as CM situational } \\
\text { awareness through overall assessment and mutual analysis of the incident. }\end{array}$ & & Assessment \\
\hline 7 & $\begin{array}{l}\text { Planning and practical clinical collaboration, defined as the overall } \\
\text { assessment and contribution of medical staff and resources. }\end{array}$ & & Triage, Treatment \\
\hline 8 & $\begin{array}{l}\text { Planning and performance of medical support logistics, defined as overall } \\
\text { assessment and contribution of medical logistics resources. }\end{array}$ & & Transport \\
\hline 9 & Comments/Examples & & Free text \\
\hline
\end{tabular}

\section{References}

1. Atkinson, M.; Jones, M.; Lamont, E. Multi-Agency Working and Its Implications for Practice. A Review of the Literature. 2007. Available online: https:/ / www.nfer.ac.uk/nfer/publications/mad01/mad01.pdf (accessed on 14 June 2021).

2. Khorram-Manesh, A.; Berner, A.; Carlström, E. Facilitating Multiagency Collaboration Before Mass Gatherings-The Development of MAGRAT (Mass Gathering Risk Assessment Tool). Biomed. J. Sci. Tech. Res. 2020, 24, 18607-18616. [CrossRef]

3. Khorram-Manesh, A.; Lönroth, H.; Rotter, P.; Wilhelmsson, M.; Aremyr, J.; Berner, A.; Andersson, A.N.; Carlström, E. Non-medical aspects of civilian-military collaboration in the management of major incidents. Eur. J. Trauma Emerg. Surg. 2017, 43, 595-603. [CrossRef] [PubMed]

4. Khorram-Manesh, A. Facilitators and constrainers of civilian-military collaboration: The Swedish perspectives. Eur. J. Trauma Emerg. Surg. 2020, 46, 649-656. [CrossRef] [PubMed]

5. Kapucu, N. Interagency communication networks during emergencies: Boundary spanners in multiagency coordination. Am. Rev. Public Adm. 2006, 36, 207-225. [CrossRef]

6. Joyce, N. Civilian-Military Coordination in the Emergency Response in Indonesia. Mil. Med. 2006, 171, 66-70. [CrossRef]

7. Kulve, H.T.; Smit, W.A. Civilian-military co-operation strategies in developing new technologies. Res. Policy 2003, 32, 955-970. [CrossRef]

8. Gil-Garcia, J.R.; Guler, A.; Pardo, T.A.; Burke, B. Characterizing the importance of clarity of roles and responsibilities in government inter-organizational collaboration and information sharing initiatives. Gov. Inf. Quart. 2019, 36, 101393. [CrossRef] 
9. Curnin, S.; Owen, C.; Paton, U.; Trist, C.; Parsons, D. Role clarity, swift trust, and multi-agency coordination. J. Conting Crisis Manag. 2015, 23, 29-35. [CrossRef]

10. Kaiser, F.M. Interagency Collaborative Arrangements and Activities: Types, Rationales, Considerations. Congressional Research Service 7-5700, R41803. 2011. Available online: https://www.fas.org/sgp/crs/misc/R41803.pdf (accessed on 12 December 2021)

11. Perrault, E.; McClelland, R.; Austin, C.; Sieppert, J. Working Together in Collaborations: Successful Process Factors for Community Collaboration. Adm. Soc. Work. 2011, 35, 282-298. [CrossRef]

12. Sienkiewicz-Małyjurek, K. Strategic Approach and Initiatives Streamlining Emergency Operations in Poland. Acad. J. Interdiscip. Stud. 2014, 3, 385-392. [CrossRef]

13. Leung, Z.C.S. Boundary Spanning in Interorganizational Collaboration. Adm. Soc. Work. 2013, 37, 447-457. [CrossRef]

14. Kożuch, B.; Sienkiewicz-Małyjurek, K. Factors of effective inter-organizational collaboration: A framework for public management. Transylv. Rev. Adm. Sci. 2016, 47, 97-115.

15. Vangen Huxham Vangen, S.; Huxham, C. Introducing the Theory of Collaborative Advantage. In The New Public Governance? Emerging Perspectives on the Theory and Practice of Public Governance; Osborne, S.P., Ed.; Routledge: London, UK; New York, NY, USA, 2010; pp. 163-184.

16. Arya, B.; Lin, Z. Understanding Collaboration Outcomes from an Extended Resource-Based View Perspective: The Roles of Organizational Characteristics, Partner Attributes, and Network Structures. J. Manag. 2007, 33, 697-723. [CrossRef]

17. Hansen, M.T.; Nohria, N. How to Build Collaborative Advantage. MIT Sloan Manag. Rev. 2004, 46, $20-30$.

18. Hardy, C.; Phillips, N.; Lawrence, T.B. Resources, Knowledge and Influence: The Organizational Effects of Interorganizational Collaboration. J. Manag. Stud. 2003, 40, 321-347. [CrossRef]

19. Kaurin, P.S. An “Unprincipled Principal”: Implications for Civil-Military Relations. Strateg. Stud. Q.-Perspect. 2021, 15, 50-68. Available online: https:/ / www.jstor.org/stable/27032896 (accessed on 1 November 2021).

20. Hodgetts, T.J. Major Incident Medical Training: A Systematic International Approach. Int. J. Disaster Med. 2003, 1, 13-20. [CrossRef]

21. Ellern, H. Military and Civilian Pyrotechnics. Chemical Publishing Company. 1968. Available online: http://www.getanewgun. com/Pyrotechnic/Pyrotechnic_Books/Fireworks_Ellernh_M_Cp.pdf (accessed on 1 November 2021).

22. Khorram-Manesh, A.; Burkle, F.M., Jr.; Phattharapornjaroen, P.; Marzaleh, M.A.; Al Sultan, M.; Mäntysaari, M.; Carlström, E.; Goniewicz, K.; Santamaria, E.; Comandante, J.D.; et al. The Development of Swedish Military Healthcare System: Part II-Re-evaluating the Military and Civilian Healthcare Systems in Crises Through a Dialogue and Study Among Practitioners. Mil. Med. 2021, 186, e442-e450. [CrossRef]

23. Rivers, F.; Speraw, S.; Phillips, K.D.; Lee, J. A review of nurses in disaster preparedness and response: Military and Civilian Collaboration. J. Homel. Secur. Emerg. Manag. 2010, 7. [CrossRef]

24. Olsen, G.R. Civil-military cooperation in crisis management in Africa: American and European Union policies compared. J. Int. Relat. Dev. 2011, 14, 333-353. [CrossRef]

25. Welton, R.S.; Hamaoka, D.A.; Broderick, P.J.; Schillerstrom, J.E. The Best of Both Worlds: Psychiatry Training at Combined Civilian-Military Programs. Acad. Psychiatry 2015, 39, 360-364. [CrossRef]

26. Wennman, I.; Wittholt, M.; Carlström, E.; Carlsson, T.; Khorram-Manesh, A. Urgent care centre in Sweden-The integration of teams and perceived effects. Int. J. Health Plan. Manag. 2019, 34, 1205-1216. [CrossRef]

27. Pollock, A.M.; Dunnigan, M.G.; Gaffney, D.; Price, D.; Shaoul, J. The private finance initiative: Planning the "new" NHS: Downsizing for the 21st century. BMJ 1999, 319, 179-184. [CrossRef]

28. Khorram-Manesh, A.; Burkle, F.M., Jr. Disasters and Public Health Emergencies-Current Perspectives in Preparedness and Response. Sustainability 2020, 12, 8561. [CrossRef]

29. Blimark, M.; Örtenwall, P.; Lönroth, H.; Mattsson, P.; Boffard, K.; Robinson, Y. Swedish emergency hospital surgical surge capacity to mass casualty incidents. Scand. J. Trauma Resusc. Emerg. Med. 2020, 28, 12. [CrossRef]

30. Marklund, L.A.; Graham, A.M.; Morton, P.G.; Hurst, C.G.; Motola, I.; Robinson, D.W.; Kelley, V.A.; Elenberg, K.J.; Russler, M.F.; Boehm, D.E.; et al. Collaboration between civilian and military healthcare professionals: A better way for planning, preparing, and responding to all hazard domestic events. Prehosp. Disaster Med. 2010, 25, 399-412. [CrossRef]

31. Avegno, J.; Moises, J.; Tatford, S.; Herbert, K.; Zickerman, E. A novel civilian-military partnership in emergency medical services during a prolonged disaster: Patient characteristics, resource utilization, and future recommendations. Ann. Emerg. Med. 2006, 48, 52. [CrossRef]

32. Stinner, M.D.J.; Wenke, J.C.; Ficke, C.J.R.; Gordon, L.C.W.; Toledano, C.J.; Carlini, A.R.; Scharfstein, D.O.; Hsu, J.R.; the Major Extremity Trauma Research Consortium (METRC); MacKenzie, E.J.; et al. Military and Civilian Collaboration: The Power of Numbers. Mil. Med. 2017, 182, 10-17. [CrossRef]

33. McCulloch, K.L.; Cecchini, A.S.; Radomski, M.V.; Scherer, M.R.; Smith, L.; Cleveland, C.; McMillan, H.P.; Davidson, L.F.; Weightman, M.M. Military-Civilian Collaborations for mTBI Rehabilitation Research in an Active Duty Population: Lessons Learned From the Assessment of Military Multitasking Performance Project. J. Head Trauma Rehabil. 2017, 32, 70-78. [CrossRef]

34. Khorram-Manesh, A.; Nordling, J.; Carlström, E.; Goniewicz, K.; Faccincani, R.; Burkle, F.M. A translational triage research development tool: Standardizing prehospital triage decision-making systems in mass casualty incidents. Scand. J. Trauma Resusc. Emerg. Med. 2021, 29, 119. [CrossRef] 
35. Naor, M. Civilian-military pooling of health care resources in Haiti: A theory of complementarities perspective. Int. J. Prod. Res. 2018, 56, 6741-6757. [CrossRef]

36. Stifter, J.; Terry, A.; Phillips, J.; Heitschmidt, M. A short report on an interprofessional mobilizer team: Innovation and impact during the COVID-19 pandemic. J. Interprof. Care 2020, 34, 716-718. [CrossRef] [PubMed]

37. Khorram-Manesh, A.; Dulebenets, M.A.; Goniewicz, K. Implementing Public Health Strategies-The Need for Educational Initiatives: A Systematic Review. Int. J. Environ. Res. Public Health 2021, 18, 5888. [CrossRef] [PubMed]

38. Burkle, F.M. Political Intrusions into the International Health Regulations Treaty and Its Impact on Management of Rapidly Emerging Zoonotic Pandemics: What History Tells Us. Prehosp. Disaster Med. 2020, 35, 426-430. [CrossRef]

39. Kettl, D.F. States divided: The implications of American federalism for COVID-19. Public Adm. Rev. 2020, 80, 595-602. [CrossRef]

40. Khorram-Manesh, A.; Carlström, E.; Hertelendy, A.J.; Goniewicz, K.; Casady, C.B.; Burkle, F.M. Does the Prosperity of a Country Play a Role in COVID-19 Outcomes? Disaster Med. Public Health Prep. 2020, 1-10. [CrossRef]

41. Amat, F.; Arenas, A.; Faló-Gimeno, A.; Muñoz, J. Pandemics meet democracy: Experimental evidence from the COVID-19 crisis in Spain. arXiv 2020. Available online: https: / / osf.io/preprints/socarxiv/dkusw / (accessed on 14 June 2021).

42. Bol, D.; Giani, M.; Blais, A.; Loewen, P.J. The effect of COVID-19 lockdowns on political support: Some good news for democracy Eur. J. Politic Res. 2021. [CrossRef]

43. Kalkman, J.P. Military crisis responses to COVID-19. J. Conting Crisis Manag. 2021, 29, 99-103. [CrossRef]

44. Mitchell, R.M.W. Rapid Response: Civilian-Military Medical Collaboration-An Everyday Medical Implementation? Available online: https:/ / www.bmj.com/content/369/bmj.m2055/rr-0 (accessed on 11 November 2021).

45. Kohn, S.; Barnett, D.J.; Leventhal, A.; Reznikovich, S.; Oren, M.; Laor, D.; Grotto, I.; Balicer, R.D. Pandemic influenza preparedness and response in Israel: A unique model of civilian-defense collaboration. J. Public Health Policy 2010, 31, 256-269. [CrossRef]

46. Heaslip, G.; Barber, E. Using the military in disaster relief: Systemizing challenges and opportunities. J. Hum. Logist. Supply Chain. Manag. 2014, 4, 60-81. [CrossRef]

47. Kwaja, C.M.A.; Olivieri, D.J.; Boland, S.; Henwood, P.C.; Card, B.; Polatty, D.P.; Levine, A.C. Civilian perception of the role of the military in Nigeria's 2014 Ebola outbreak and health-related responses in the North East region. BMJ Mil. Health 2021, e001696. [CrossRef]

48. Goniewicz, K.; Goniewicz, M.; Burkle, F.M., Jr. The Territorial Defence Force in Disaster Response in Poland: Civil-Military Collaboration during a State of Emergency. Sustainability 2019, 11, 487. [CrossRef]

49. Page, M.J.; McKenzie, J.E.; Bossuyt, P.M.; Boutron, I.; Hoffmann, T.C.; Mulrow, C.D.; Shamseer, L.; Tetzlaff, J.M.; Akl, E.A.; Brennan, S.E.; et al. The PRISMA 2020 statement: An updated guideline for reporting systematic reviews. BMJ 2021, 372, n71. [CrossRef]

50. Health Evidence Quality Assessment Tool (HEQAT). Available online: https://www.healthevidence.org/documents/ourappraisal-tools/QA_Tool\&Dictionary_10Nov16.pdf (accessed on 14 June 2021).

51. Oxford Dictionary Online. Available online: https://www.oxfordlearnersdictionaries.com/ (accessed on 14 June 2021).

52. Nicholas, D.; Clark, D.; Herman, E. ResearchGate: Reputation uncovered. Learn. Publ. 2016, 29, 173-182. [CrossRef]

53. Kirchherr, J.; Charles, K. Enhancing the sample diversity of snowball samples: Recommendations from a research project on anti-dam movements in Southeast Asia. PLoS ONE 2018, 13, e0201710. [CrossRef]

54. Baltar, F.; Brunet, I. Social research 2.0: Virtual snowball sampling method using Facebook. Internet Res. 2018, 22, 55-74. [CrossRef]

55. Khorram-Manesh, A.; Plegas, P.; Högstedt, Å.; Peyravi, M.; Carlström, E. Immediate response to major incidents: Defining an immediate responder! Eur. J. Trauma Emerg. Surg. 2020, 46, 1309-1320. [CrossRef]

56. Ma, H.; Dong, J.P.; Zhou, N.; Pu, W. Military-civilian cooperative emergency response to infectious disease prevention and control in China. Mil. Med. Res. 2016, 30, 39. [CrossRef]

57. Leprince, C. Obstacles to civil-military collaboration in conflict zones when organizations go to war. Etudes Int. 2017, 48, 37-61. [CrossRef]

58. Brandt, M.M. Civilian-military partnerships. J. Trauma Acute Care Surg. 2017, 82, 977-978. [CrossRef]

59. Khorram-Manesh, A. Flexible Surge capacity-Public health, public education, and disaster management. Health Promot. Perspect. 2020, 10, 175-179. [CrossRef]

60. Knudson, M.M.; Elster, E.; Bailey, J.A.; Johannigman, J.A.; Bailey, P.V.; Schwab, C.W.; Kirk, G.G.; Woodson, J.A. Military-Civilian Partnerships in Training, Sustaining, Recruitment, Retention, and Readiness: Proceedings from an Exploratory First-Steps Meeting. J. Am. Coll. Surg. 2018, 227, 284-292. [CrossRef]

61. Simpson, S.A.; Goodwin, M.; Thurstone, C. Implementation and Evaluation of a Military-Civilian Partnership to Train Mental Health Specialists. Mil. Med. 2019, 184, e184-e190. [CrossRef]

62. Cancian, M.E. Use of Military Forces in the COVID-19 Emergency. Center for Strategic \& International Studies. (CSIS). Available online: https:/ / www.csis.org/analysis/use-military-forces-covid-19-emergency (accessed on 14 June 2021).

63. van der Wal, H.; van Dongen, T.T.; Vermeulen, C.F.; Bruce, J.L.; Bekker, W.; Manchev, V.; Kong, V.; van Waes, O.; Clarke, D.L.; Hoencamp, R. Developing a blueprint for a civilian-military collaborative program in trauma training for Northern European countries: A South African experience. Injury 2020, 51, 70-75. [CrossRef]

64. Tsai, Y.-D.; Tsai, S.-H.; Chen, S.-J.; Chen, Y.-C.; Wang, J.-C.; Hsu, C.-C.; Chen, Y.-H.; Yang, T.-C.; Li, C.-W.; Cheng, C.-Y. Pilot study of a longitudinal integrated disaster and military medicine education program for undergraduate medical students. Medicine 2020, 99, e20230. [CrossRef] 
65. Watts, G.; Wilkinson, E. Military Planning. What the NHS is learning from the British army in the COVID-19 crisis. BMJ 2020, 369, m2055. [CrossRef]

66. Khorram-Manesh, A.; Robinson, Y.; Boffard, K.; Örtenwall, P. The History of Swedish Military Healthcare System and Its Path Toward Civilian-Military Collaboration From a Total Defense Perspective. Mil. Med. 2020, 185, e1492-e1498. [CrossRef] [PubMed]

67. Pollock, K.; Steen, R. Total Defence Resilience: Viable or Not During COVID-19? A Comparative Study of Norway and the UK. Risk Hazards Crisis Public Policy 2020, 12, 73-109. [CrossRef] [PubMed]

68. Pasquier, P.; Luft, A.; Gillard, J.; Boutonnet, M.; Vallet, C.; Pontier, J.-M.; Duron-Martinaud, S.; Dia, A.; Puyeo, L.; Debrus, F.; et al. How do we fight COVID-19? Military medical actions in the war against the COVID-19 pandemic in France. BMJ Mil. Health 2020. [CrossRef] [PubMed]

69. Samuel, N.; Epstein, D.; Oren, A.; Shapira, S.; Hoffmann, Y.; Friedman, N.; Shavit, I. Severe pediatric war trauma: A militarycivilian collaboration from retrieval to repatriation. J. Trauma Acute Care Surg. 2021, 90, e1-e6. [CrossRef]

70. Puckett, L.M. Civilian-Military coordination in disaster preparedness and response. Nat. Hazard Rev. 2021, $22,04021005$. [CrossRef]

71. Gad, M.; Kazibwe, J.; Quirk, E.; Gheorghe, A.; Homan, Z.; Bricknell, M. Civil-military cooperation in the early response to the COVID-19 pandemic in six European countries. BMJ Mil. Health 2021. [CrossRef]

72. Khorram-Manesh, A.; Burkle, F.M.; Goniewicz, K.; Robinson, Y. Estimating the Number of Civilian Casualties in Modern Armed Conflicts-A Systematic Review. Front. Public Health 2021, 9, 765261. [CrossRef]

73. Corlett, J.; McConnachie, T. Delivering resilience training to pre-registration student nurses in partnership with a reservist military organization: A qualitative study. Nurse Educ. Today 2021, 97, 104730. [CrossRef]

74. Sultan, M.A.S.; Khorram-Manesh, A.; Carlström, E.; Berli, J.; Sörensen, J. Impact of Virtual Disaster Collaboration Exercises on Disaster Leadership at Hospitals in Saudi Arabia. Int. J. Disaster Risk. Sci. 2021, 12, 879-889. [CrossRef]

75. Graneheim, U.H.; Lundman, B. Qualitative content analysis in nursing research: Concepts, procedures and measures to achieve trustworthiness. Nurse Educ. Today 2004, 24, 105-112. [CrossRef]

76. Khorram-Manesh, A.; Angthong, C.; Pangma, A.; Sulannakarn, S.; Burivong, R.; Jarayabhand, R.; Örtenwall, P. Hospital Evacuation; Learning from the Past? Flooding of Bangkok 2011. J. Adv. Med. Med. Res. 2013, 4, 395-415. [CrossRef]

77. Angthong, C.; Kumjornkijjakarn, P.; Pangma, A.; Khorram-Manesh, A. Disaster Medicine in Thailand: A Current Update. Are We Prepared? J. Med. Assoc. Thai 2012, 95, 42-50.

78. Phattharapornjaroen, P.; Glantz, V.; Carlström, E.; Dahlén Holmqvist, L.; Khorram-Manesh, A. Alternative Leadership in Flexible Surge Capacity-The Perceived Impact of Tabletop Simulation Exercises on Thai Emergency Physicians Capability to Manage a Major Incident. Sustainability 2020, 12, 6216. [CrossRef]

79. Shah, S.; Diwan, S.; Kohan, L.; Rosenblum, D.; Gharibo, C.; Soin, A.; Sulindro, A.; Nguyen, Q.; Provenzano, D.A. The technological impact of COVID-19 on the future of education and health care delivery. Pain Physician 2020, 23, S367-S380. [CrossRef] [PubMed]

80. Moreno, C.; Wykes, T.; Galderisi, S.; Nordentoft, M.; Crossley, N.; Jones, N.; Cannon, M.; Correll, C.U.; Byrne, L.; Carr, S.; et al. How mental health care should change as a consequence of the COVID-19 pandemic. Lancet Psychiatry 2020, 7, 813-824. [CrossRef]

81. Dwivedi, Y.K.; Hughes, D.L.; Coombs, C.; Constantiou, I.; Duan, Y.; Edwards, J.S.; Gupta, B.; Lal, B.; Misra, S.; Prashant, P.; et al. Impact of COVID-19 pandemic on information management research and practice: Transforming education, work and life. Int. J. Inf. Manag. 2020, 55, 102211. [CrossRef]

82. Kramer, A.; Kramer, K.Z. The potential impact of the COVID-19 pandemic on occupational status, work from home, and occupational mobility. J. Vocat. Behav. 2020, 119, 103442. [CrossRef] [PubMed]

83. Khorram-Manesh, A.; Berlin, J.; Carlström, E. Two Validated Ways of Improving the Ability of Decision-Making in Emergencies; Results from a Literature Review. Bull. Emerg. Trauma 2016, 4, 186-196. [PubMed] 